\title{
The AmeriFlux Network: A Coalition of the Willing
}

$5 \quad{ }^{1}$ School of Public and Environmental Affairs, Indiana University - Bloomington

$6 \quad{ }^{2}$ Southwest Watershed Research Center, United States Agricultural Department, Agricultural Research 7 Service, 2000 E Allen Road,

8 Tucson, AZ 85719 USA.

$9{ }^{3}$ University of Wisconsin-Madison, Department of Atmospheric and Oceanic Sciences, Madison, WI, United States

$11{ }^{4}$ Department of Biology, University of New Mexico, Albuquerque, NM 87131, USA

$12{ }^{5}$ School of Natural Resources, University of Arizona, Tucson, AZ, USA

$13{ }^{6}$ Climate and Ecosystem Sciences Division, Lawrence Berkeley National Laboratory, Berkeley, $14 \quad$ California, USA

15

16 Keywords: eddy covariance, network science, climate change, carbon cycle, water cycle, big data, 17 environmental observation networks 
25 Abstract: AmeriFlux scientists were early adopters of a network-enabled approach to ecosystem science 26 that continues to transform the study of land-atmosphere interactions. In the 20 years since its formation, 27 AmeriFlux has grown to include more than 260 flux tower sites in the Americas that support continuous 28 observation of ecosystem carbon, water, and energy fluxes. Many of these sites are co-located within a 29 similar climate regime, and more than 50 have data records that exceed 10 years in length. In this 30 prospective assessment of AmeriFlux's strengths in a new era of network-enabled ecosystem science, we 31 discuss how the longevity and spatial distribution of AmeriFlux data make them exceptionally well suited 32 for disentangling ecosystem response to slowly evolving changes in climate and land-cover, and to rare 33 events like droughts and biological disturbances. More recently, flux towers have also been integrated 34 into environmental observation networks that have broader scientific goals; in North America these 35 include the National Ecological Observatory Network (NEON), Critical Zone Observatory network 36 (CZO), and Long-Term Ecological Research network (LTER). AmeriFlux stands apart from these other 37 networks in its reliance on voluntary participation of individual sites, which receive funding from diverse 38 sources to pursue a wide, transdisciplinary array of research topics. This diffuse, grassroots approach 39 fosters methodological and theoretical innovation, but also challenges network-level data synthesis and 40 data sharing to the network. While AmeriFlux has had strong ties to other regional flux networks and 41 FLUXNET, better integration with networks like NEON, CZO and LTER provides opportunities for new 42 types of cooperation and synergies that could strengthen the scientific output of all these networks. 
47 Section 1: Introduction and Overview. Ecosystem science is being transformed by the

48 proliferation of environmental observation networks, which aggregate observations from a large number 49 of biomes, often for long time-periods, and make these data widely available (Baldocchi, 2008; Jones et

50 al., 2010; Peters et al., 2008. Rapid advances in instrument design and cyber-infrastructure have advanced

51 network-enabled approaches by fostering data sharing and reuse through centralized repositories

52 (Hampton et al., 2013; Peters et al., 2014; Rundel et al., 2009). Network-enabled approaches produce

53 generalizable environmental knowledge through integration of distributed observations. This shift

54 towards network science has been motivated by an increasingly complex set of socio-ecological questions

55 - often related to the interactions between humans, ecosystems, and the global climate system - that

56 necessitate synthesis of information from many biomes and at policy- and management-relevant scales

57 (Jones et al., 2010; Schimel, 2011).

Scientists who study land-atmosphere interactions, and in particular those who focus on the

59 biosphere-atmosphere exchange of $\mathrm{CO}_{2}$ and water, have been at the forefront of this shift towards

60 network-enabled approaches (Baldocchi, 2008). How much $\mathrm{CO}_{2}$ ecosystems remove from the atmosphere

61 each year, and how much water they use in the process, are critical questions guiding our understanding

62 of trends in climate and water resources (Booth et al., 2012; Friedlingstein et al., 2014; Jung et al., 2010).

63 These ecosystem carbon and water fluxes are sensitive to slowly evolving processes, including ongoing

64 climate change and recovery from disturbance, which frequently occur at large spatial scales. These

65 processes are difficult to study using short-term manipulative experiments, single-factor gradient studies,

66 and other traditional tools of inquiry in the ecological and environmental sciences.

In response to this research challenge, the AmeriFlux network of carbon and water flux tower

68 sites was formed more than 20 years ago by a pioneering group of scientists who were separately

69 monitoring these fluxes at individual sites and site-clusters. At the same time, other, continental-and

70 international flux tower networks were initiated, including FLUXNET (Baldocchi et al., 2001) and

71 EuroFlux (Aubinet et al., 1999), with others soon to follow (e.g. Oz-flux and Asia-Flux, Beringer et al., 
72 2016; Mizoguchi et al., 2009). Written as AmeriFlux celebrates its $20^{\text {th }}$ anniversary, this paper focuses on 73 science that leverages AmeriFlux observations, while also recognizing present and potential synergies 74 between AmeriFlux and its sister flux networks around the globe. The individual field sites of AmeriFlux are organized around eddy-covariance flux towers, which support the continuous monitoring of the net ecosystem exchange of $\mathrm{CO}_{2}(\mathrm{NEE})$, evapotranspiration (ET),

77 and other land-atmosphere fluxes (Baldocchi, 2003; Goulden et al., 1996). Since AmeriFlux was formed,

78 eddy covariance flux towers have also become an important part of other environmental observation 79 networks, including three networks of the National Science Foundation (NSF): the National Ecological 80 Observation Network (NEON, Schimel et al., 2007), the Critical Zone Observatory network (CZO, White 81 et al. 2015), and Long-Term Ecological Research Network (LTER, Hobbie et al., 2003). The missions of 82 NEON, CZO and LTER are supportive of, but not exclusively focused on, understanding land-atmosphere 83 interactions.

91 instrumentation and measurements; this design allows for data to be collected in the same way

92 everywhere, to foster intra- network synthesis, and is not tailored to site-specific questions. LTER and

93 CZO lie between these two extremes; Sites in both networks receive their base funding from a centralized 94 source (NSF) and have mandates to collect and share certain types of data as a result. However, specific 95 research questions and methods are PI-driven and linked to the ecological, geological, and topographical 96 context of each site (Hobbie et al., 2003; Richter and Billings, 2015). 
A principle objective of this paper is to offer a prospective assessment of the research questions

98 and knowledge gaps that are well matched to the unique operational characteristics of the AmeriFlux

99 network, in the context of the attributes of the other networks. We will also identify some challenges

100 associated with AmeriFlux's grass-roots, bottom-up approach to network science, and the potential to

101 address these challenges through cross-network integration and synergies. Here, we do not provide a

102 thorough review of all the significant knowledge advances already enabled by AmeriFlux; those success

103 stories are well described elsewhere (Baldocchi, 2008; Knapp et al., 2012; Law, 2005; Richter and

104 Billings, 2015). Rather, the retrospective sections of this manuscript are focused on identifying the broad

105 research questions that have historically been well-matched to AmeriFlux's operational approach.

106 To meet our objectives, we will first compare and contrast the scope, size, and organization of the

107 major environmental networks in North America that support flux towers (Section 2), with a particular

108 focus on highlighting the unique attributes of AmeriFlux. In Section 3, we will review the range of

109 scientific inquiry that has been historically supported by AmeriFlux's unique approach to network-

110 enabled science. In Section 4, we will explore the likely future research directions for AmeriFlux

111 scientists. Finally, in Section 5, we review some of the challenges associated with AmeriFlux's approach

112 to network activity, and highlight ways in which those challenges can be overcome through synergies

113 with other networks. 


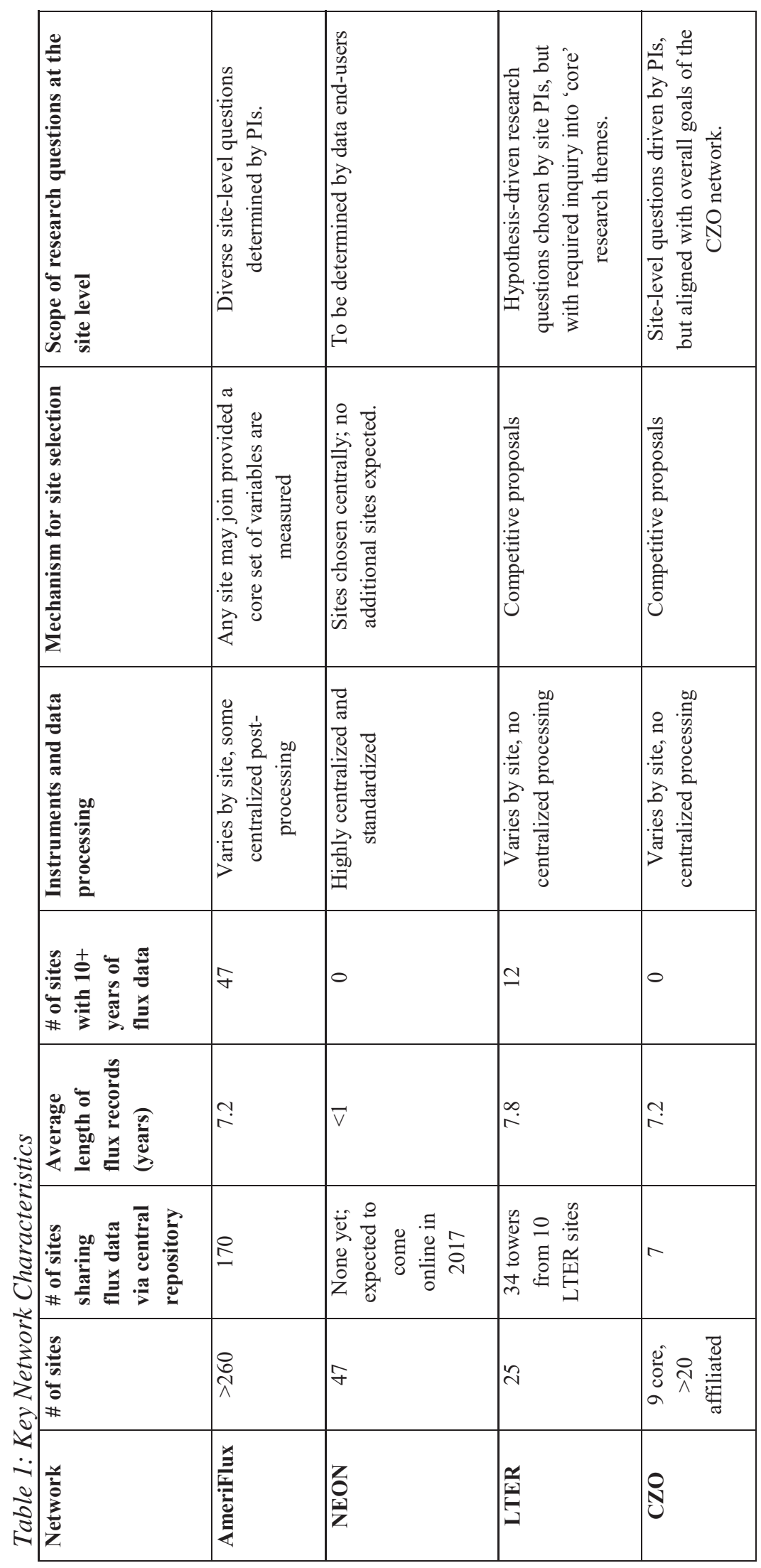

省

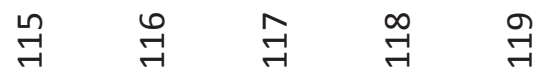




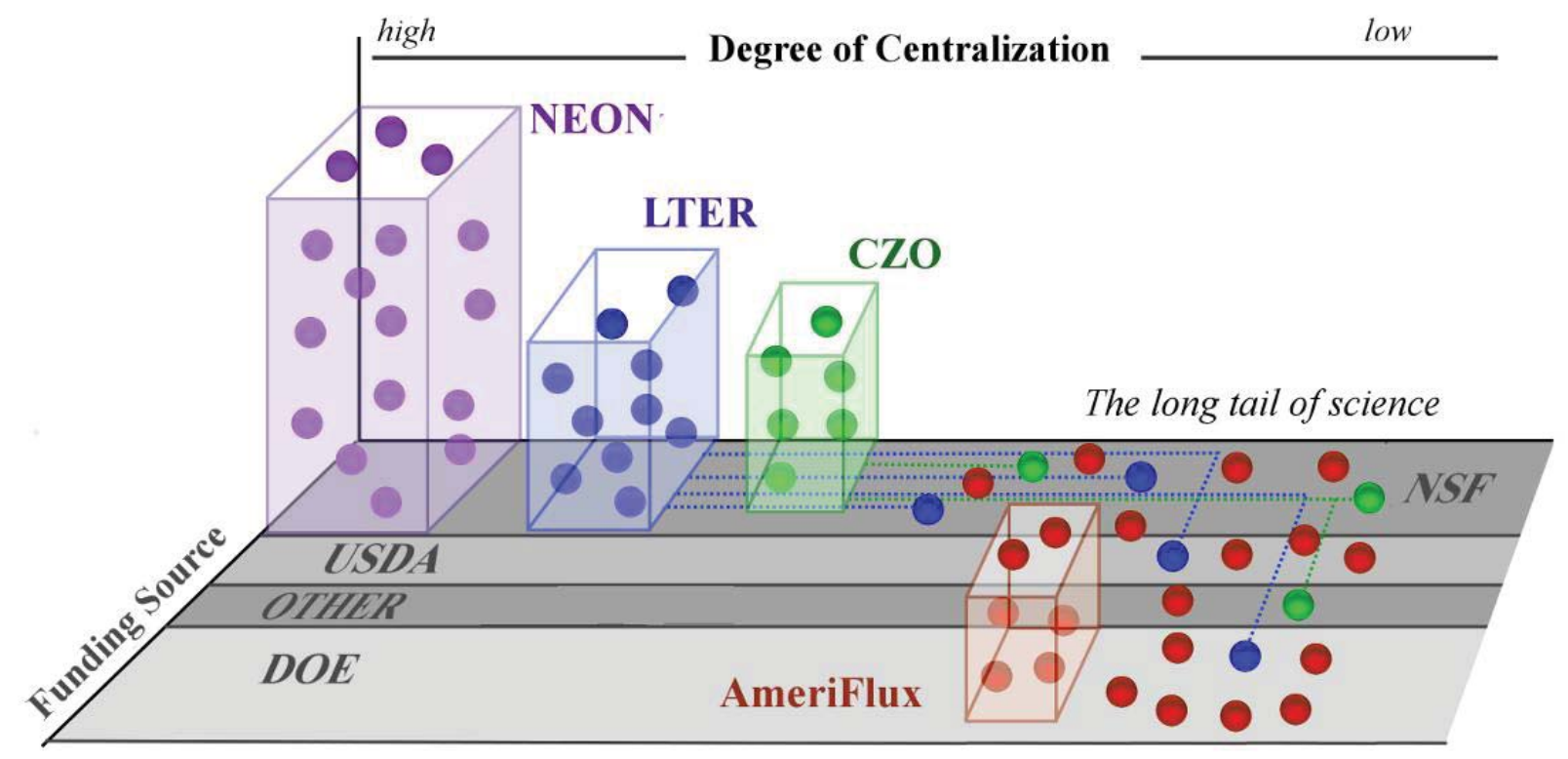

Figure 1: A conceptual illustration of funding sources and organizational approach of the networks considered here, focusing specifically on their flux towers. The spheres represent individual tower sites; those that are contained in boxes represent towers that are funded directly by the network, while those residing outside of boxes leverage funding from a non-centralized source. On one end of the spectrum resides NEON, a network with sites that are funded and maintained exclusively by a central governing body. On the other end the spectrum is AmeriFlux, a distributed network of PI-managed towers largely funded by relatively small grants or allocations from a diverse range of sources. LTER and CZO lie in between - while support for network sites is centralized, site-specific research activities are PI-driven and often leverage funding from other, non-network sources. 
122 Section 2: Comparing and contrasting the flux tower networks. This section focuses on highlighting

123 the key similarities and differences among the flux tower networks operating in North America, with a

124 goal of identifying AmeriFlux's most distinctive operational attributes.

125 2.1: AmeriFlux's grassroots approach to measuring carbon and water fluxes. Established in 1996,

126 AmeriFlux is a PI-driven 'coalition' of more than 260 registered tower sites, with approximately 170

127 having shared data to the network at the time of this writing. The domain covers North, South, and

128 Central America, but most sites are located in North America. AmeriFlux relies on a bottom-up

129 organizational approach: PIs establish and maintain sites to answer a diverse set of research questions, but

130 willingly share data in support of broader community efforts to understand, predict, and manage the

131 global carbon cycle. Although funding for individual tower sites comes from a range of sources (Figure

132 1), the US Department of Energy (US-DOE) has historically invested heavily in centralized support for

133 data quality control, archiving, processing, and distribution (Boden et al., 2013), as well as annual

134 meetings. Since 2013, US-DOE has organized its financial support for the network under the umbrella of

135 the 'AmeriFlux Management Project' (AMP).

The primary objectives of the AMP are to (1) maximize the quality of AmeriFlux data and its

137 usability by a broad community; (2) expand the network's impact as a field laboratory for basic research

138 and Earth System Model (ESM) improvement; (3) foster innovative measurements; and (4) sustain and

139 extend the long-term record of carbon, water and energy fluxes being collected by a cohort of AmeriFlux

140 'core' sites, (approximately 17\% of all sites in the network). AmeriFlux sites are non-standardized with

141 respect to their instrumentation and site-level data processing, though the AMP is actively working to

142 infuse a standardized approach into network-level data organization, post-processing, and quality control.

143 AMP also continues longstanding US-DOE support for a portable eddy covariance system (PECS;

144 Billesbach et al., 2004; Schmidt et al., 2012) that is deployed to 8 to 12 sites per year to compare flux and

145 meteorological measurements, and evaluate calibration protocols and safety practices. 

supporting the study of interactions and feedbacks among a complex suite of ecological processes and drivers (Schimel et al., 2007). This network sustains a -coordinated array of 'terrestrial' monitoring sites

149 (incl. EC flux, $n=47$ ) and 'aquatic' sites (no EC flux, $n=34$ ), alongside in-situ sample collections and 150 airborne remote sensing. NEON terrestrial EC flux sites are classified as "core" $(n=20$, expected 30-year 151 study period) or "relocatable" ( $n=27$, expected 5- to 10-year study period), and were selected to 152 maximize the network's representativeness of the large gradients in land cover and climate in the study 153 domain (Keller et al., 2008). Flux towers are an important component of the sampling design of the terrestrial sites, where information about soil biophysics and plant phenology, productivity, and species composition will also be routinely collected. In contrast to AmeriFlux, a central technical and governing body manages all sampling, and data are highly standardized. At the mid-point of 2017, turbulent and storage flux data were being collected at many NEON sites, with corresponding data products at four processing levels intended to come online throughout 2017.

\section{3: Studying slowly-evolving processes through the Long-Term Ecological Research Network}

(LTER). NSF's LTER network is the oldest of the four considered here, initiated in 1982 to support research into ecological processes that evolve over long time scales (Franklin et al., 1990; Hobbie et al., 2003). It has grown to include 25 sites representing diverse biomes in the US, the Caribbean, and Antarctica, with new sites added occasionally through a competitive process tailored for a specific biome. Because the LTER program places strong emphasis on context-dependent, hypotheses-driven research questions developed by site-level teams, it can be described as "bottom-up." In contrast to AmeriFlux, however, all LTER funding comes from a single source (NSF), and sites must collect and share data

167 pertaining to one or more of five core research areas. Cross-site collaboration has been a focus of LTER 168 since its inception (Johnson et al. 2010) and is facilitated through a centralized "data portal" and competitive funding for synthesis projects. A portion of LTER sites support eddy covariance measurements, with decisions about instrumentation and data processing are made by the site PIs. 


\section{4: A common approach to integrating hydrology, geology, and ecology through Critical Zone}

172 Observatories (CZOs). The Critical Zone refers to earth's thin outer shell, extending from the bedrock,

173 through aquifers and soils, and upwards to the top of vegetative canopies (Richter and Billings, 2015).

174 Within the last decade, an international network of observatories has been established to study mass and

175 energy flows in the Critical Zone, and to understand their relevance for economic and environmental

176 goods and services (White et al., 2015). NSF funds nine individual sites in the continental US and Puerto

177 Rico, and an additional $\sim 20$ sites have registered as CZO affiliates in North America (White et al. 2015).

178 Like LTER, CZO is "bottom-up" in that site-level work is led by cross-disciplinary teams studying links

179 between geological and surface processes that are unique to each site. The site-specific research questions

180 and observations all fall under an umbrella of a shared conceptual framework and a common set of

181 measurements, including flux tower observations (Chorover et al., 2012). Decisions about measurement

182 approach and technique are decentralized and site-specific, but data are shared to a centralized repository.

2.5: Spatial and temporal representativeness of flux towers. AmeriFlux sites are not efficiently

distributed to achieve representativeness. Their sheer number, however, spans wide gradients in climate conditions and vegetation communities and affords rich multi-site design (Figure 2). For example, many sites are part of smaller site-clusters that are co-located in similar macro-climate environments $(\sim 30 \mathrm{~km}$,

187 Figure 2) but are distributed across a range of land cover and edaphic conditions (Anderson-Teixeira et al., 2011; Novick et al., 2015; Scott et al., 2015). These site-clusters thus allow for investigation of how, for example, land management, hydrologic conditions, or disturbance affect ecosystem fluxes and processes. In contrast, there are 47 planned NEON sites, 34 LTER-affiliated flux towers, and 9 flux-tower CZO sites. By design, NEON sites are distributed to represent the range of bio-climate conditions in

192 North America (Figure 2), and no two NEON sites are co-located to within $30 \mathrm{~km}$ of each other. LTER and CZO-affiliated tower sites are smaller in number and represent fewer climate regimes. AmeriFlux is also distinguished by the longevity of its data records. While the average length of tower data records is 7 

datasets exceeding 10 years in length - far more than any other network.
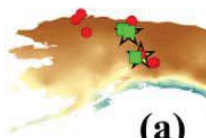

(a)

Annual Precipitation

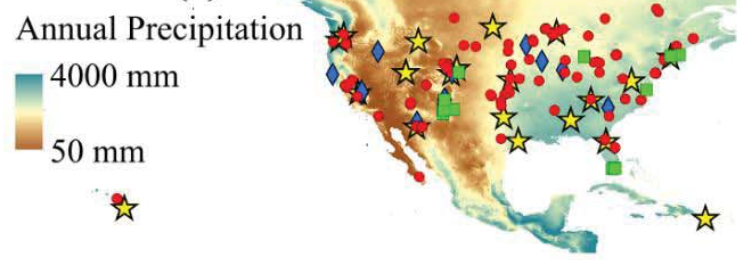

(c)

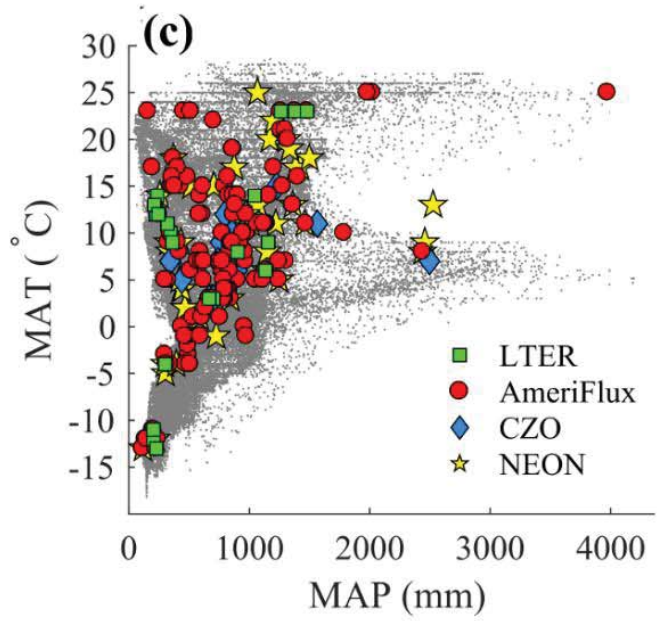

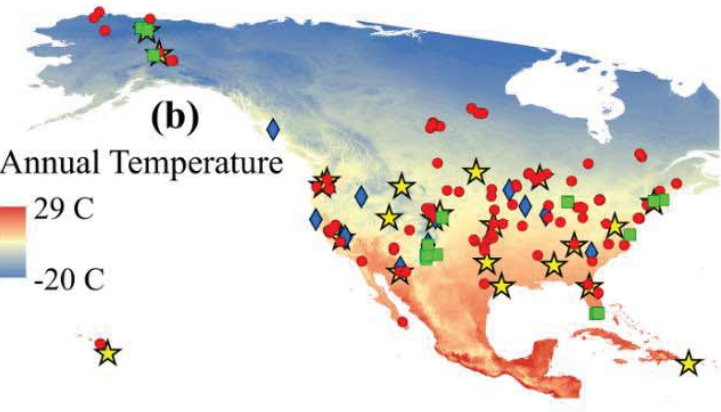

- LTER

- Ameriflux

$\diamond \mathrm{CZO}$

it NEON

(d)

Figure 2: The location of various network flux towers on a background of mean annual precipitation (panel a), mean annual temperature (b), and the MAP-MAT phase plane (c). The AmeriFlux sites are limited to those that have submitted data to the network. The analysis is also limited to the core CZO sites, excluding CZO "affiliated" sites that do not necessarily host flux towers. LTER sites are limited to those that share flux tower data with the LTER network. Panel d shows the number of network sites colocated to within $30 \mathrm{~km}$ of at least one other tower, within and across networks. The maps are restricted to North America, where the majority of AmeriFlux sites is located. 
In addition, a new network, the Long-Term Agro-ecosystem Research (LTAR), initiated by the

211 USDA Agricultural Research Service, was recently established to investigate the effects of management

212 on agro-ecosystems (Walbridge and Shafer, 2011). Some of the 23 LTAR network sites already host

213 AmeriFlux-affiliated towers, and plans to instrument many others could significantly increase the richness

214 of agro-ecosystems in the AmeriFlux database. Similarly, new towers are being established in Canada and 215 Alaska as part of the NASA-supported Arctic-Boreal Vulnerability Experiment (ABoVE). Because the 216 operational approach and cyber-infrastructure of these newer networks are still largely under

217 development, they are not a focus of this manuscript, though we recognize the potential for future 218 synergies between AmeriFlux and these new network initiatives.

220 Section 3: Leveraging the strengths of AmeriFlux. In this section, we discuss

221 challenging research questions that have historically been well matched to AmeriFlux's unique attributes,

222 which include spatial representativeness and site clustering, long data records, and the diversity of

223 research questions that fuel the activities of individual sites.

224 3.1: Characterizing the interannual variability in carbon and water fluxes . Long-term flux data

225 records are full of surprises, often revealed only after many years of data collection. For example, in the

226 long-running Morgan-Monroe State Forest AmeriFlux site, estimates of the annual net ecosystem

227 exchange of $\mathrm{CO}_{2}$ (or NEE) were relatively constant for the first 5 years of data record (between -300 and -

$228350 \mathrm{~g} \mathrm{C} \mathrm{m}^{-2}$ year, Figure 3a). Unexpectedly, carbon uptake increased considerably for the second five

229 years (e.g., NEE became more negative, between -375 and $-400 \mathrm{~g} \mathrm{C} \mathrm{m}^{-2}$ ), driven in part by longer

230 growing seasons (Dragoni et al., 2011). Thereafter, the size of the carbon sink was noticeably reduced,

231 driven in part by a coincident increase in aridity (Brzostek et al., 2014) and a severe drought event in

2322012 (Roman et al., 2015). 
In fact, most flux records are characterized by significant interannual variability (IAV) of carbon and water-vapor exchange (see Figure 3b-d, Desai, 2010; Hui et al., 2003; Yuan et al., 2009; Zscheischler et al., 2016). This high degree of IAV underscores the need for long-term flux monitoring, as estimates of flux magnitudes and IAV can be biased when based on only a few years of data (Figure 3). In many sites, flux records must reach timescales of decades (or longer) in order to adequately sample the IAV of relevant meteorological drivers (Chu et al., 2017). Many AmeriFlux site data records are now sufficiently long to characterize the statistics of flux IAV and to characterize and quantify its drivers.
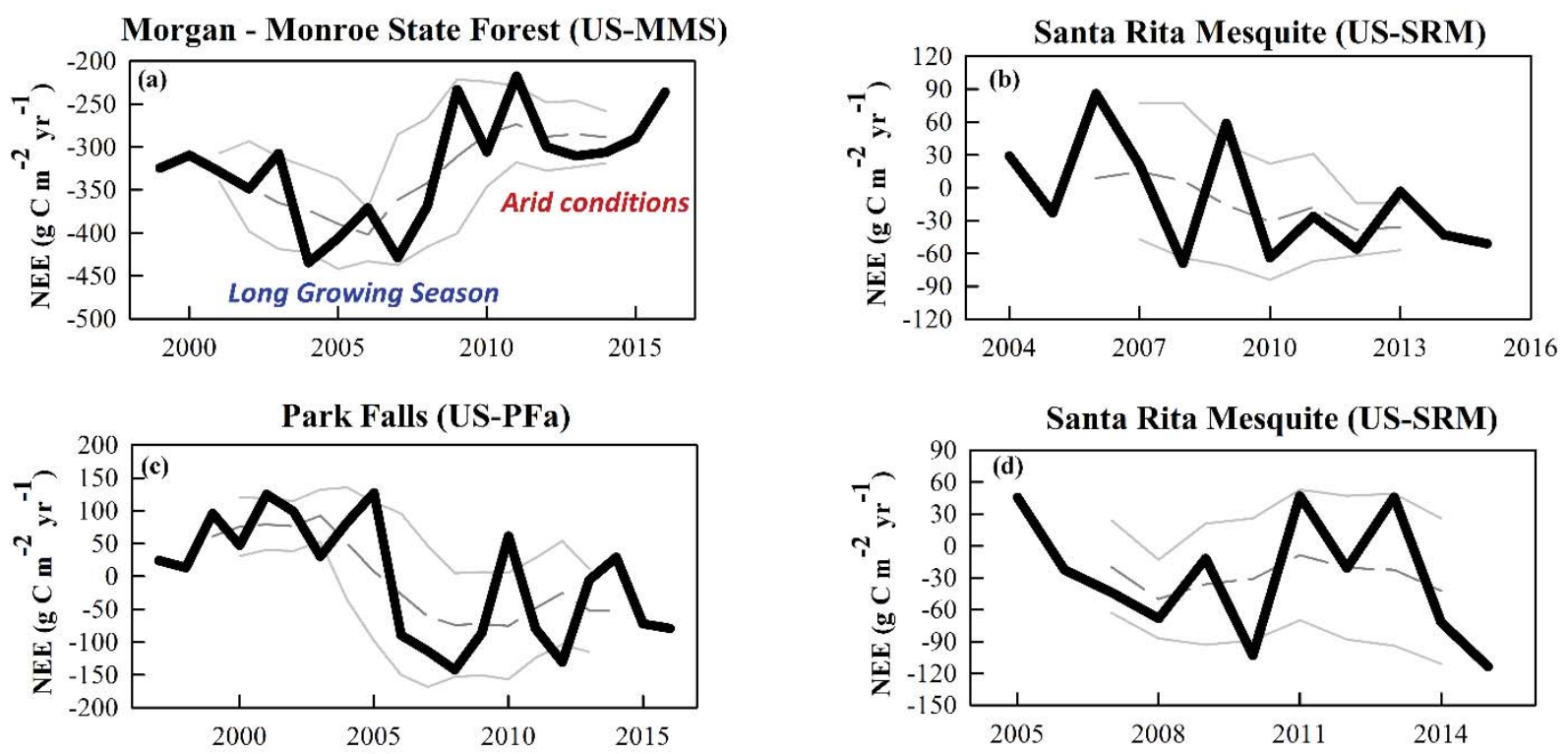

240

241

242

243

244

245

246

247

248

249

250

Figure 3: Annual NEE from several long-running AmeriFlux core sites. The thick black line shows the annual data. The dashed gray line shows the 5-year moving average, and the thin gray lines show the 5year moving standard deviation.

3.2: Detecting the influence of extreme events on ecosystem fluxes: Because AmeriFlux records are long, they contain many unusual events including droughts, floods, wildfires, and insect outbreaks. For example, roughly half of AmeriFlux sites experienced at least one severe spring or summer drought month, defined as a Palmer Drought Severity Index (PSDI, Alley 1984) value less than -3. A quarter of sites have experienced multiple years with at least one drought month (Figure 4). AmeriFlux data collected during these events have already been used to study (1) differential drought impacts on gross 
primary productivity (GPP) and respiration (Schwalm et al., 2010; Schwalm et al., 2012), (2) interactions between early season phenology and later season drought (Wolf et al., 2016), (3) plant response to drying 253 soil as compared to drying air (Novick et al., 2016a; Rigden and Salvucci, 2017), and (4) ecosystem 254 response to exogenous structural disturbances like insect outbreaks and logging (Amiro et al., 2010).

Pluvial Years

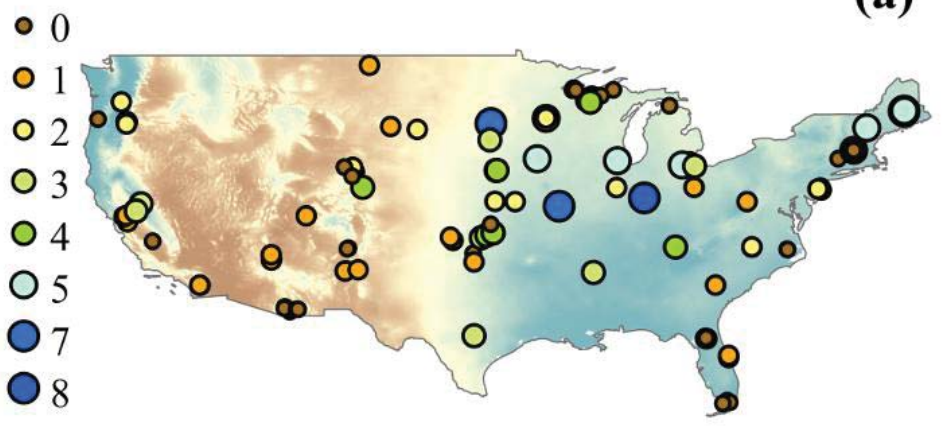

Figure 4 : Panel a shows the number of pluvial years in AmeriFlux records from the continental United States, where a pluvial years includes at least one growing season month of PDSI $>3$. Panel $b$ shows the number of drought years at each site, defined as a year with at least one growing season month of PDSI< -3. Background map is mean annual precipitation.

Drought Years

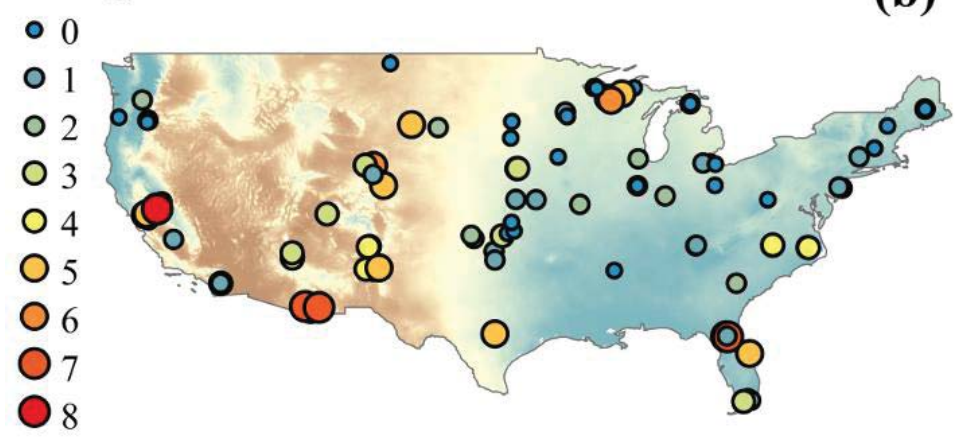

(b)

(a) 
each individual event in the absence of a long-term record. For example, in 2012 much of the Midwestern U.S. was affected not only by severe drought but also by a very early start to the growing season (Roman et al., 2015; Wolf et al., 2016). Thus, while the 2012 annual NEE in many drought-affected sites was not

270 particularly anomalous, comparing the drought year fluxes to those recorded in non-drought years

271 allowed for the effects of the early growing season and drought event to be separately quantified (Roman

272 et al., 2015).

273

3.3: Disentangling land cover effects from climate effects. Because AmeriFlux is a relatively dense

274 network (Figure 2), many sites occupy similar climate envelopes, and approximately 30\% of AmeriFlux

275 sites are co-located to within $30 \mathrm{~km}$ of at least one other tower site (Figure 2d). Consequently, it is

276 possible to subsample from the AmeriFlux database to form site-clusters that experience similar climate

277 conditions but different land cover, enabling the disentangling of effects of climate and vegetation on

278 fluxes. As an early example of the site-cluster approach, the Boreal Ecosystem-Atmosphere Study

279 (BOREAS) project relied on a series of intensive field campaigns to assess the carbon sink strength of

280 boreal ecosystems of different burn ages and vegetation cover (Sellers et al. 1997). Since then, AmeriFlux

281 site-clusters have been used to evaluate effects of climate and disturbance history on NEE (Law et al.,

282 2004), assess theoretical predictions for the carbon uptake potential of mature forests (Novick et al., 2015;

283 Stoy et al., 2008), and quantify the influence of site-level factors in determining GPP and ET in semi-arid

284 (Biederman et al., 2016) and temperate (Desai et al., 2008a) biomes. Additionally, the Forest Accelerated

285 Succession Experiment (FASET) at the University of Michigan Biological Station used deliberate

286 landscape-scale manipulation within a tower footprint to bridge the gap between observational and

287 experimental approaches for understanding land-atmosphere interactions (Gough et al., 2013).

3.4: Benchmarking models and remote-sensing products. AmeriFlux has a long history of validating remote-sensing products and informing and benchmarking land surface models for plant productivity, 290 water use, and other ecosystem processes (Huntzinger et al., 2012; Levis et al., 2012; Running et al., 2004; Stöckli et al., 2008). Although the spatial resolution of ESMs is much larger than that of eddy 
covariance tower footprints, AmeriFlux sites broadly sample from the plant functional types represented by models. Thus, network data can be used to characterize rate controls and climate dependencies of $\mathrm{CO}_{2}$ and water fluxes in different plant communities, providing the means to redress problems with current models and develop new modeling approaches (Huntzinger et al., 2012; Luo et al. 2012). These efforts benefitted from methods to estimate the uncertainties in flux observations (Hollinger et al., 2004;

297 Richardson et al., 2006), a pre-requisite for data-model fusion studies. Additionally, recent advances in 298 scaling methods allow better rectification of tower footprints to model grid cells (Xiao et al. 2011; Xu et al., 2017), and guide the number of sites needed to accurately capture net flux for a given uncertainty (Hill et al., 2017).

Similarly, AmeriFlux data have played an important role in evaluating reanalysis and gridded meteorology products (Decker et al., 2012), downscaling climate model output to local regions (Vuichard and Papale, 2015), and benchmarking the ever-evolving suite of remotely-sensed information on vegetation distribution and function (Nishida et al., 2003; Xiao et al., 2008). Recent advances in detection of plant solar-induced fluorescence (SIF) for mapping plant stress and photosynthesis (Frankenberg et al., 2014; Verma et al., 2017; Yang et al., 2015), hyperspectral visible-to near-IR imaging for mapping of foliar traits and chemistry (Serbin et al., 2015), and detection of moisture variation from satellite platforms (e.g. SMAP, Jones et al. in press, and ECOSTRESS, Fisher et al., 2017) all suggest a rich era of future satellite missions that will require a robust ground network like AmeriFlux. Complimenting these efforts, many AmeriFlux sites have installed ancillary sensors to detect ecosystem-scale properties that are linked to satellite observations (including Phenocam cameras, Brown et al., 2016, and COSMOS soil

312 moisture sensors, Zreda et al., 2012).

314 diversity of measurement approaches, across a wide range of environmental and infrastructure conditions, 315 AmeriFlux has been a source of innovation in instrumentation and measurement approaches, and continues to act as a testbed as new instruments and processing methods become available. For example, 

tube effects in closed-path analyzers (Burba et al., 2011; Hollinger et al., 1999; Novick et al., 2013; Su et al., 2004), self-heating effects in open path gas analyzers (Burba et al., 2008), and the influence of sonic anemometer orientation on the measurement of vertical wind speed (Frank et al., 2016; Van der Molen et al., 2004). AmeriFlux scientists have also played a critical role in developing approaches to correct for instrument biases and processing procedures, for example by applying spectral corrections (Hollinger et al., 1999; Massman, 2000; Massman, 2001), selecting an appropriate coordinate rotation scheme (Lee et al., 2005; Wilczak et al., 2001), and averaging and detrending eddy covariance time series (Moncrieff et

325 al., 2005).

3.6: Scientific community building . AmeriFlux's grassroots, community-oriented approach to networkenabled science enables interactions across sites, disciplines, and career stages. Because individual sites must choose to opt-in to AmeriFlux, affiliation reflects each PI's recognition of the value of the community enterprise. PIs share technical know-how to elevate the standards of other sites, share their data with a specific goal of advancing science beyond their site-level questions, and pursue broader management- and policy-oriented scientific aims that are best achieved through network-enabled 332 approaches. Historically, AmeriFlux's collaborative data use policy has fostered the development of 333 synthesis products by large collaborative teams (Amiro et al., 2010; Richardson et al., 2012; Xiao et al., 334 2011). These teams foster inter-personal relationships that benefit other network activities requiring 335 voluntary participation from community members, such as the annual AmeriFlux meetings, technical workshops focused on sharing best practices, coordination of meetings with the U.S. Global Change

337 Research Program's "North American Carbon Program”, PECS site visits, active list serves, and 338 AmeriFlux sponsorship of Flux Course (www.fluxcourse.org). Flux Course is a two-week workshop for 339 early career scientists, with many AmeriFlux scientists serving as guest instructors. For early career 340 scientists in particular, network collaboration has many benefits, including increased publication rates, 341 greater visibility, opportunities for extra-institutional mentorship, and the chance to learn best practices 
342 for publication and grant writing (Goring et al., 2014). Informal collaborations promoted by interactions 343 at AmeriFlux workshops, PI meetings, and the Flux Course can also lay foundations for future, more

344 formal operational collaborations (Hara et al., 2003; Lewis et al., 2012).

\section{Section 4: Looking forward - Emerging research areas for AmeriFlux}

scientists. In this section, we turn to the likely avenues of future research to be conducted by AmeriFlux scientists, again drawing connections between the scope of the research and the network's that the investigators planned to use AmeriFlux data in project activities, or planned to generate new observations from flux tower sites in North, Central our Latin America. It was not clear whether all of these towers were already registered AmeriFlux sites, though they are all eligible to register with AmeriFlux (i.e. they represent current or potential AmeriFlux sites). After the $60+$ abstracts were

357 compiled, they were searched for a wide range of keywords. Those that appeared in at least three (or 5\%)

358 of the abstracts are included in Table 2.

4.1: An enduring focus on carbon cycling. The words "carbon" or " $\mathrm{CO}_{2}$ " appeared in nearly $90 \%$ of project abstracts, suggesting that AmeriFlux scientists will continue to leverage network data to reduce

361 uncertainty in the global carbon cycle. As AmeriFlux data records continue to grow, richer sets of

362 information will be available to close remaining gaps in our understanding of current and future

363 ecosystem carbon cycling (Friedlingstein et al., 2014), and inform more confident fingerprinting of trends

364 in the fluxes driven by ongoing climate change. The large number of studies that include a modeling 
focus $(85 \%)$, remotely sensed data (37\%), and evapotranspiration (27\%) suggest that understanding of carbon and water cycling at regional and continental scales remains a research priority for the community.

371 on GPP estimates derived from SIF. Flux towers provide a platform for near-surface SIF measurements,

372 as well as independent estimates of GPP against which to benchmark SIF observations from towers and

373 satellites (Frankenberg et al., 2014; Yang et al., 2015). Several other active projects include a focus on

374 carbonyl sulfide (COS), which is a "sulfur-containing analogue of $\mathrm{CO}_{2}$ " (Asaf et al., 2013) that can be

375 taken up by plants and thereby serve as a proxy for GPP (Campbell et al., 2015; Seibt et al., 2010). This

376 approach is particularly well suited for testing at flux tower sites, because COS flux can be measured

377 directly using the eddy covariance technique (Billesbach et al., 2014; Wehr et al., 2017).

Table 2: Results from active grant keyword search ( $n=61$ active projects)

\begin{tabular}{|c|c|c|}
\hline Search term & Number of grants & Percent of grants \\
\hline carbon or $\mathrm{CO}_{2}$ & 53 & 0.88 \\
\hline model, models or modeling & 51 & 0.85 \\
\hline remote sensing & 22 & 0.37 \\
\hline management & 19 & 0.32 \\
\hline evapotranspiration & 16 & 0.27 \\
\hline energy balance, energy cycling & 14 & 0.23 \\
\hline tropics, tropical & 12 & 0.20 \\
\hline drought & 11 & 0.18 \\
\hline GPP & 11 & 0.18 \\
\hline disturbance & 10 & 0.17 \\
\hline economic & 10 & 0.17 \\
\hline land cover, land use & 10 & 0.17 \\
\hline agriculture & 7 & 0.12 \\
\hline hydrology & 7 & 0.12 \\
\hline arctic & 6 & 0.10 \\
\hline belowground & 5 & 0.08 \\
\hline methane & 5 & 0.08 \\
\hline
\end{tabular}




\begin{tabular}{|c|l|l|}
\hline physiology & 5 & 0.08 \\
\hline fluorescence or SIF & 4 & 0.07 \\
\hline blue carbon & 3 & 0.05 \\
\hline carbonyl Sulfide (COS or OCS) & 3 & 0.05 \\
\hline nitrous oxide & 3 & 0.05 \\
\hline
\end{tabular}

4.2: An emerging focus on land management. The phrases "land management" and "agricultural systems" were mentioned in a significant number of project abstracts $(32 \%$ and $12 \%$ of projects, respectively), positioning AmeriFlux scientists to better constrain our understanding of how human land use impacts biogeochemical and hydrologic cycling (Bohrer et al., 2015). Numerous AmeriFlux research groups have already demonstrated the usefulness of aggregating flux data from management-oriented siteclusters to investigate carbon cycle impacts of tilling, irrigation, and winter cover crops in the Corn Belt (Baker and Griffis, 2005; Verma et al., 2005), thinning and harvesting in US forests (Clark et al., 2004; Law et al., 2003), and landscape-scale shifts in land use and management regimes (Runkle et al., 2017; Stoy et al., 2008). Moving forward, the newly formed USDA-ARS LTAR network, which includes several AmeriFlux-affiliated towers, may play a critical role in elucidating links between agricultural management and land-atmosphere interactions. 2 made explicit mention of "energy balance" in the project abstract. Energy balance closure (or the lack thereof) in flux tower data has been a subject of investigation since the inception of AmeriFlux

394 (Baldocchi and Vogel, 1996, Wilson et al. 2002). Generalized solutions continuet to remain elusive 395 (Foken et al., 2008; Stoy et al., 2013), and thus will undoubtedly persist as a focus for future research. 396 Nonetheless, despite these methodological challenges, flux tower data are increasingly being used to 397 understand how biophysical mechanisms directly alter energy balance and local temperature. For 398 example, Juang et al. (2007) demonstrated that, in the temperate zone, surface temperature is lower over 399 an evergreen and deciduous forest when compared to an adjacent grassland site, due principally to higher evapotranspiration and sensible heat flux in the forests. In contrast, Lee et al. (2011) demonstrated that in 
boreal ecosystems, surface temperature tends to be warmer over forested sites compared to nearby grasslands, due to the strong radiative effects of low forest albedo in wintertime when open areas are snow-covered. Using data from two savannah ecosystems, Baldocchi and Ma (2013) explored interactions

404 between land cover, surface and air temperature, and seasonality. These research foci are well-aligned 405 with an emerging recognition of the potential for land management schemes to mitigate climate change 406 not only through their effect on carbon uptake, but also through direct effects on local hydrology and 407 surface temperature (Ellison et al., 2017).

4.4: Other greenhouse gases. A small but significant fraction of active grant proposals are explicitly

409 focused on measuring fluxes of non- $\mathrm{CO}_{2}$ greenhouse gases like methane ( $8 \%$ of studies) and nitrous oxide 410 (5\% of studies), enabled by rapid advancements in gas analyzer technology and data analysis (McDermitt 411 et al., 2011; Detto et al., 2011; Mammarella et al., 2010). As the number of sites reporting these gas fluxes 412 continues to grow, network-enabled approaches for understanding $\mathrm{CO}_{2}$ and $\mathrm{H}_{2} \mathrm{O}$ fluxes will be applied to 413 better understand and predict the dynamics of the biosphere-atmosphere exchange.

\section{Section 5: Challenges associated with a grassroots approach to network}

\section{science, and opportunities for cross-network syntheses and synergies. Our}

417 discussion thus far has highlighted how AmeriFlux's 20 year history of PI-driven network science

418 positions the network to continue addressing pressing knowledge gaps in our understanding of carbon and

419 water cycle science. However, AmeriFlux's "bottom-up approach" also presents significant challenges to

420 network operations and syntheses (see Table 3). In this section, we discuss these challenges in more detail

421 and highlight ways they could be addressed through cross-network synergies that would benefit all

422 relevant networks, allowing them to fully capitalize on the potential of network-enabled ecosystem

423 science to generate scalable, generalizable information for mitigating and managing environmental

424 change. 


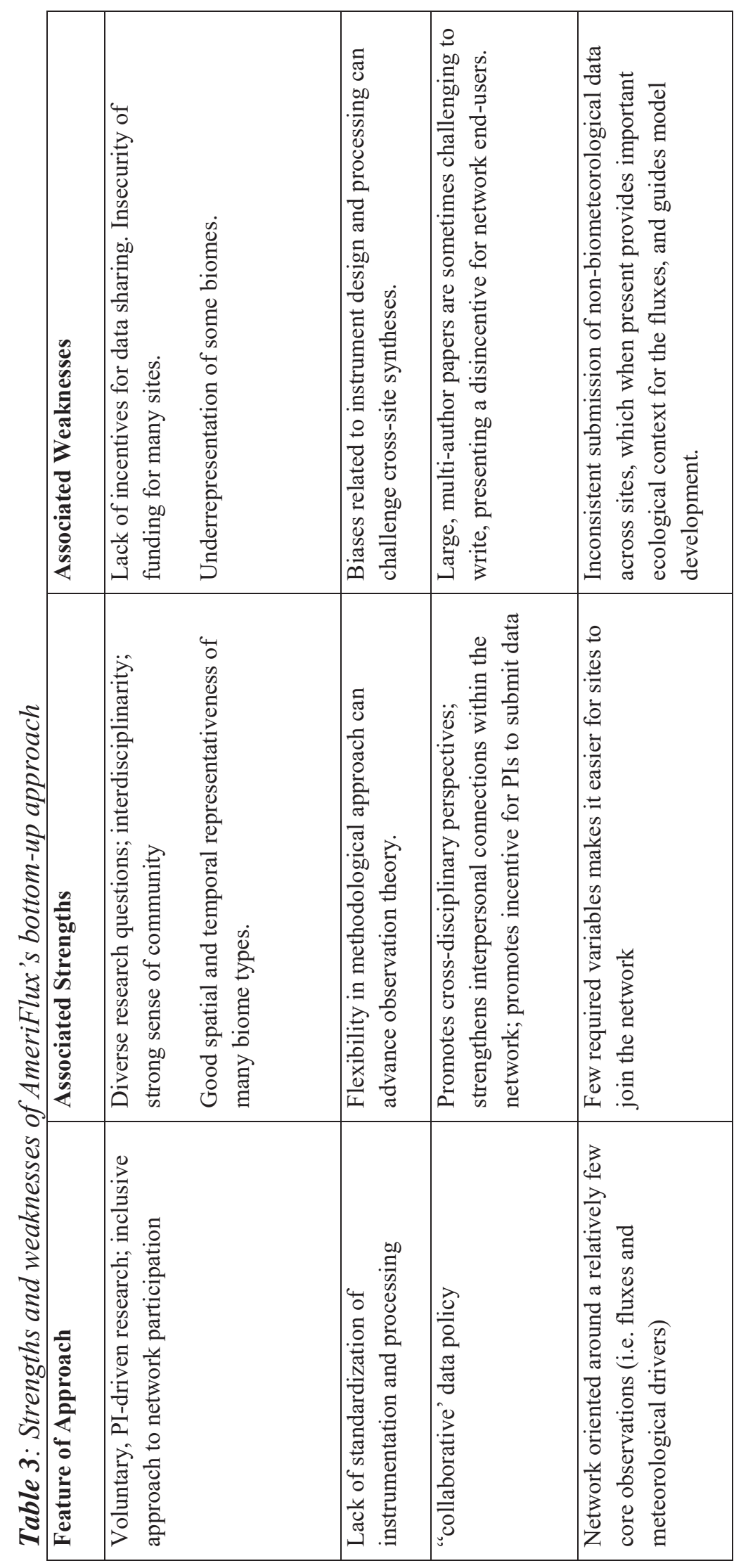

N 

represents a challenge for many environmental fields that are adopting network-enabled approaches

429 (Peters et al., 2014). In the case of AmeriFlux, and perhaps because eddy covariance methodology 430 evolved in concert with the use of eddy covariance data in a network setting, methodological biases in 431 flux observations have been exceptionally well studied. As discussed in subsection 3.5, these biases have 432 many sources, including the instruments, post-processing of high-frequency data, and the approach for 433 detecting and gapfilling half-hourly observations collected during periods of low turbulence when 434 turbulent fluxes are not representative of ecosystem fluxes. Efforts to partition measured NEE into its 435 principal components - GPP and ecosystem respiration - are further sensitive to the choice of partitioning approach (Lasslop et al., 2010; Reichstein et al., 2005; van Gorsel et al., 2009).

Fortunately, observations from the AmeriFlux PECS have revealed that biases due to site-level instrumentation and flux processing decisions tend to be small (on the order of $\sim 8 \%$ for $\mathrm{CO}_{2}$ fluxes, $5 \%$

439 for $\mathrm{H}_{2} \mathrm{O}$ fluxes, and 2\% for sensible heat fluxes, Schmidt et al., 2012). Similarly, biases due to the choice 440 of gapfilling and partitioning approaches are also on the order of 5 to $10 \%$ (Desai et al., 2008b).

441 Moreover, biases due to instrumentation or processing choice are usually not in the same direction and 442 may be partially cancelled through cross-site syntheses. Furthermore, post-processing approaches to 443 gapfilling and partitioning are becoming increasingly standardized, due to the recent release of the 444 FLUXNET2015 data product (Pastorello et al. 2017), and available to the community as R-codes or 445 online tools (e.g. Reddyproc, Reichstein and Moffat, 2014). A particularly important feature of the 446 FLUXNET2015 product is its focus on quantifying the uncertainty in flux estimates linked to the choice 447 of gapfilling and partitioning. Moving forward, calculating these uncertainties will become the purview of 448 regional networks like AmeriFlux; access to these post-processing results should motivate sites to join, or 449 continue submitting data to, AmeriFlux, and offer expanded opportunities for cross-network integration. 
instruments that are best suited for conditions at their site. Open-path gas analyzers, for example, may be

453 a good choice for solar-powered installations because they use less power than closed-path analyzers, but

454 would be a poor choice in humid or polluted environments where fog or dust frequently cloud the optical

455 path. Similarly, post-processing approaches designed to minimize the contribution of advection to the flux

456 records (e.g. van Gorsel et al. 2009) may be a particularly good choice in areas of complex terrain, where

457 advection from cold-air drainage frequently dominates nocturnal flux regimes (Novick et al. 2016b).

458 Thus, networks relying on a highly standardized approach to observation and processing are also exposed 459 to measurement bias, with a greater likelihood that the bias errors will be in the same direction. .. Ample opportunities also exist to coordinate standardization of flux data processing across

461 networks, with many efforts already well underway. NEON is already generating a new level of

462 harmonization and standardization of flux tower methodology which will be of significant benefit to

463 AmeriFlux scientists. For example, open-source eddy covariance codes are being developed by NEON for

464 broad application (Metzger et al., in press). At the same time, continued efforts to evaluate uncertainty in

465 flux records linked to the choice of instrumentation and data processing will be difficult using NEONs

466 centralized design, but should continue to be a hallmark of AmeriFlux's PI-driven approach. Indeed,

467 AmeriFlux scientists have been at the forefront of reviewing NEON sensor design and protocols through

468 leadership in NEON's Technical Working Groups (TWGs) and Science, Technology, \& Educational

469 Advisory Committee (STEAC).

$470 \quad$ 5.2: Rewards and incentives for voluntary data sharing . Much of the science conducted by

471 AmeriFlux investigators occurs in the so-called "long tail of science" (Heidorn, 2008, Figure 1), where

472 projects are relatively small in size and scope, and are funded through diverse mechanisms. With the

473 exception of AmeriFlux Core Sites, which are contractually obligated to supply data to the network in a

474 timely fashion, most AmeriFlux sites have no data sharing mandate. Undoubtedly, many AmeriFlux

475 scientists shared data altruistically. In addition, the benefits of AmeriFlux's collaborative approach to data

476 sharing and community building, addressed in detail in subsection 3.6, have also historically served as 
478 yet to upload flux data records (Table 1), Furthermore, the number of sites contributing data to the

479 network appears to have decreased in recent years (Figure 5), even as the number of sites has continued to 480 grow. Curators of the FLUXNET2015 data product have noted difficulty in encouraging scientists to 481 submit data of the necessary quality (Chu et al., 2017).

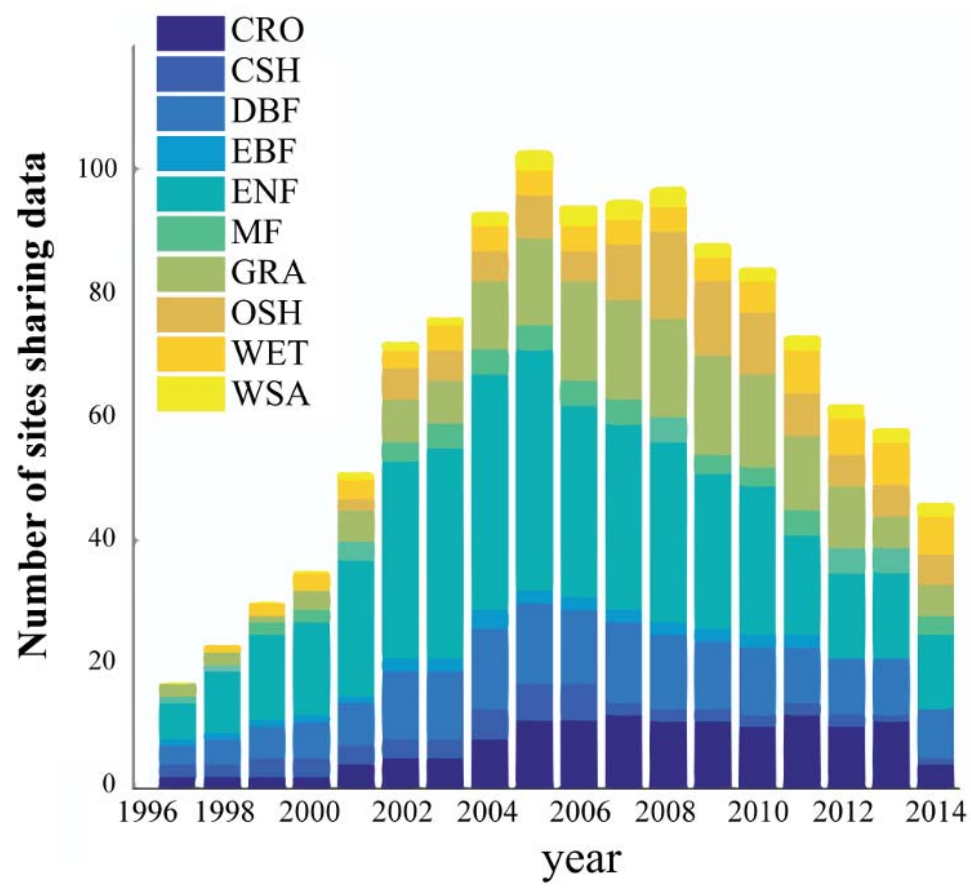

Figure 5: AmeriFlux data availability, organized by plant functional type and year of collection. Abbreviations are: $C R O=$ cropland, $C S H=$ closed shrubland, $D B H=$ deciduous broadleaf forest, $E B F$ = evergreen broadleaf forest, $E N F=$ evergreen needleleaf forest, $M F=$ mixed forest, GRA = grassland, OSH = open shrubland, WET = wetland, WSA = woody savannah.

The difficulty of extracting data from the long-tail of science -- generated by multiple projects run by individual PIs - challenges network-enabled approaches across many fields of environmental science and ecology (Goring et al., 2014; Hampton et al., 2013; Reichman et al., 2011). However, in the case of Ameriflux, which relies on voluntary participation, the problem is a particularly important one to solve. Many obstacles to data sharing are not technological but rather sociological (Reichman et al., 2011), and include: (1) fear of losing "rights" to one's data, (2) concerns that others will misinterpret observations, 
and (3) a dearth of metrics in formal evaluations of scientific success that reflect the time required to

495 prepare and curate shared datasets (Goring et al. 2014; Hampton et al., 2013; Reichman et al., 2011).

496 Strategies to overcome these obstacles include institutionalizing evaluation metrics that better reward data

497 sharing and team-based collaboration (Goring et al., 2014), and the publication of peer-reviewed datasets

498 with digital object identifier (DOI) numbers (Reichman et al., 2011), which AmeriFlux has recently

499 adopted. Putting recommendations like these into practice would be to the benefit of all the networks

500 discussed here, and represents a significant synergistic opportunity.

501

\section{3: Flux towers as integrated ecosystem research sites . As we move past AmeriFlux's 20-year} milestone, we have the opportunity to consider the controls of carbon, water and energy balance over decades with more data - and more rigor. The genesis of the eddy covariance technique is in biometeorology, and much of the question-oriented research emerging from the network has focused on linking patterns in whole ecosystem fluxes to meteorological conditions at seasonal and interannual timescales (as reviewed in Baldocchi et al. 2008). These studies are useful for diagnosing sensitivities of land-atmosphere exchanges to ongoing climate and land use change and are requisite, but not sufficient, for constructing a mechanistic understanding of the processes that control ecosystem energy, carbon, and water cycling.

These processes are driven by ecosystem components operating at scales much smaller than a tower footprint. For example, GPP integrates a cellular level processes (photosynthesis) that typically occurs across multiple species and/or canopy layers, and is linked to whole-plant hydraulic function. Similarly, ecosystem respiration reflects both autotrophic and heterotrophic contributions occurring through multiple layers of the vegetative canopy and the soil. Because these individual components may respond differently to climate change and other biophysical forcings, understanding the relative contribution of each component to the stand-level fluxes is necessary to understand how ecosystems will respond to environmental change. 
520 mechanistic understanding of ecosystem fluxes. For example, soil and tissue respiration measurements

521 can help to constraint estimates of the differential contribution of autotrophic and heterotrophic

522 respiration to ecosystem respiration (Zobitz et al., 2008; Maurer et al., 2016; Phillips et al. 2017, Ryan et

523 al., 1997; Zha et al., 2007), particularly when they are conducted within experimental root exculsions or

524 other manipulations. Similarly, leaf- and tree-level eco-physiological measurements, including

525 observations of leaf gas exchange, sap flux, and xylem vulnerability, can be leveraged to understand how

526 carbon uptake and water loss differ between species, in different canopy positions, or for plants of

527 different age and height (Roman et al. 2015, Oishi et al. 2008, Fisher et al. 2007, Irvine et al. 2004). Eddy

528 covariance records can be augmented and extended at even longer timescales by repeated censuses of

529 forest ecosystems and metrics of inter-annual variability in growth derived from tree rings (Babst et al.,

530 2014, Dye et al. 2016, Montane et al., in press). Linking fluxes to the canopy composition, age, and

531 structure is particularly important for understanding flux sensitivity to processes like succession,

532 disturbance recovery, and management regimes shifts, which can drive large changes in species

533 composition and stand structure over timescales much longer than the lifespan of a typical flux tower.

Process-level studies at AmeriFlux sites, where results can be upscaled and compared to the

535 whole-ecosystem exchange of carbon, water and energy, provides an advantage for those seeking to 536 improve terrestrial ecosystem models or use these models as integrating tools (Wang et al. 2017). Non-

537 biometeorological observations can be integrated with tower fluxes through "data assimilation," which

538 refers to the process of directly informing model states or parameters with observations (Zobitz et al.,

539 2011). Virtually all recent advances in weather forecasting have been driven by improved assimilation of

540 observations in meteorological models (Kalnay, 2003), and a similar revolution is underway in ecosystem

541 modeling (Braswell et al 2005; Moorcroft, 2006: Moore et al 2008; Dietze et al., 2014; Dietze, 2017).

542 Model-data fusion techniques can be used to compare the information contained in measurements

543 collected at different spatial scales, including eddy covariance, soil respiration, leaf area index, litterfall,

544 and woody biomass data (Richardson et al., 2010, Keenan et al. 2013). Data assimilation is also useful for 
testing mechanistic hypotheses by altering the model structure (Sacks et al., 2006; Zobitz et al., 2008),

546 illustrating one pathway by which network-supported observations datasets can be used to answer

547 hypothesis-oriented research questions which have historically dominated ecological fields of inquiry.

5.4: Education and training - As the number of AmeriFlux sites has grown, the community of AmeriFlux data end users has also expanded from a relative small group of specialists to a broad group of

551 scientists including biometeorologists, ecosystem scientists, hydrologists, microbial ecologists, soil

552 scientists, remote sensing scientists and Earth system modelers. Many current users of the data have not

553 visited an AmeriFlux site in person, and may be unfamiliar with the sources of uncertainty and bias in

554 flux records that are well known to scientists who collect the data firsthand. This gap in expertise between 555 data providers and data users, which will also likely challenge NEON, represents an additional constraint 556 on the utility of cross-site syntheses; for example, it is not uncommon to see tower-derived estimates of 557 GPP referred to as 'observations' in the literature, even though they are largely modeled products. training opportunities focused on core principles of flux tower data generation and end use. Chief among these is "Flux Course", described in subsection 3.6, which should be viewed as a useful training resource

561 for scientists using flux observations from all the networks. NEON is also beginning to sponsor

562 workshops to provide scientists with the skills needed to conduct cross-site syntheses, including events 563 focused on data from their airborne platform. Similarly, LTER's All-Scientists Meeting, held every 2 to 3 564 years, features many community-driven working groups focused on within- and cross-network synergies 565 that should be of utility and interest to AmeriFlux scientists. 


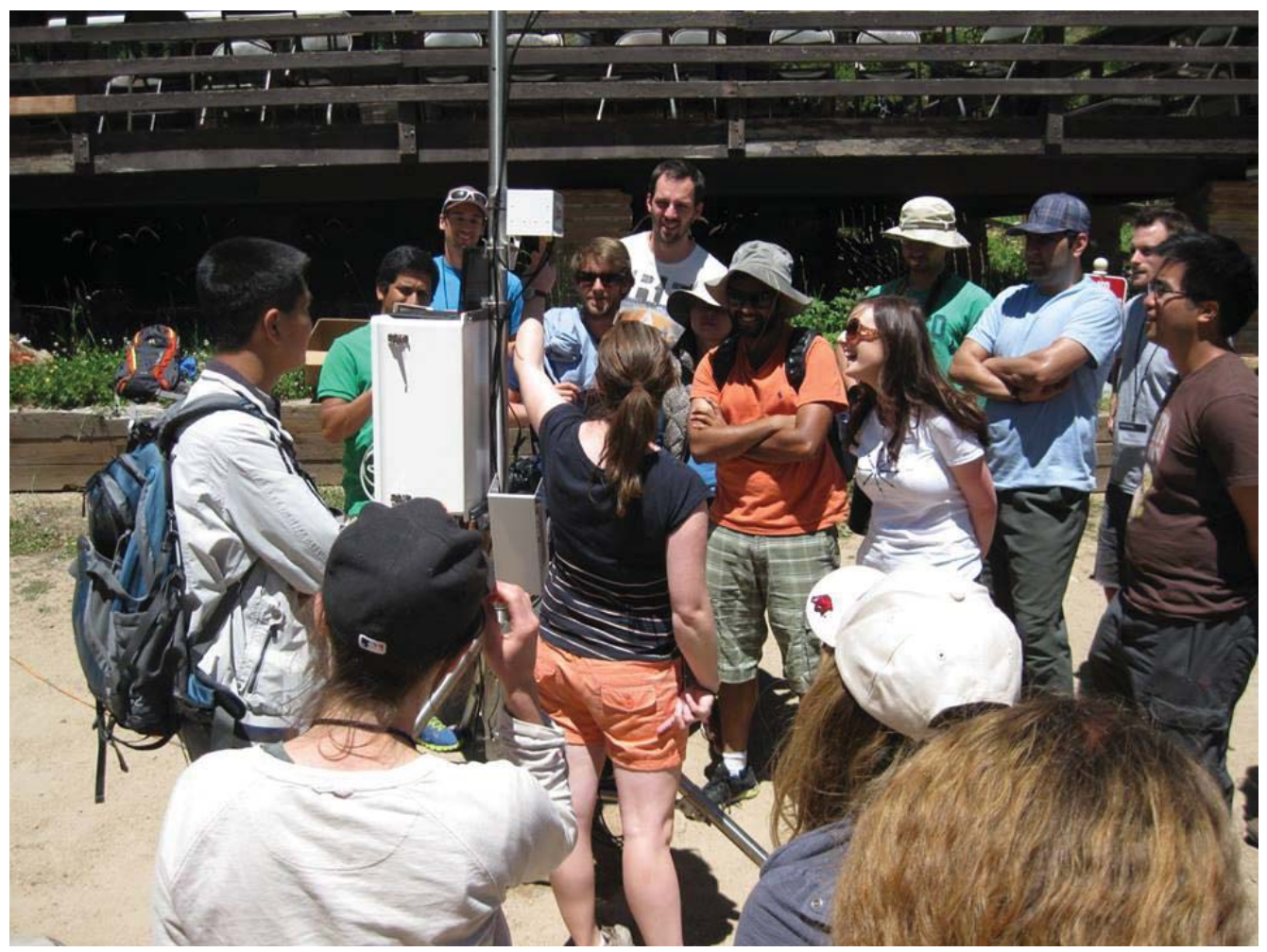

567 Figure 6 Flux Course students engage in peer-learning about the basics of eddy covariance 568 instrumentation. Photo by Edward Swiatek.

Section 6: Conclusion. AmeriFlux scientists were early adopters of a network-enabled approach to

571 studying land-atmosphere interactions, and have a 20-year history of leveraging biosphere-atmosphere

572 flux observations to understand the mechanistic controls on local- to continental-scale carbon and water

573 cycling. More recently, flux tower observations have become an important component of NEON, CZO

574 and LTER network activities; in this paper, we assessed past and future research activities which are

575 particularly well suited for AmeriFlux's unique approach to network science. The length of AmeriFlux

576 records make them especially useful for investigating the causes of interannual flux variability and for

577 fingerprinting the effects of extreme events. The spatial representativeness of AmeriFlux sites, including

578 the existence of many co-located "site-clusters," should motivate continued efforts to use AmeriFlux data

579 to disentangle climate versus vegetative controls on ecosystem function, and to benchmark ESMs.

580 AmeriFlux's bottom-up operational approach positions AmeriFlux scientists to continue to lead the 
581 development of novel methodologies, and merge flux tower and biometric data at the site level to

582 investigate a host of multi-disciplinary research questions. Challenges for AmeriFlux related to data

583 standardization, data sharing, and the merging of ecosystem-scale flux observations with leaf-, tree- and

584 plot-scale biometric data persist. Ample opportunities exist to address these challenge via cross-network

585 synergies that would benefit of all networks supporting flux tower observations to inform understanding

586 of, and solutions for, environmental challenges at policy- and management-relevant scales.

588 Acknowledgements: The authors would like to thank the AmeriFlux PIs for sharing their data to the

589 network, noting that most do so voluntarily. The authors acknowledge support from the AmeriFlux

590 Management Project, administered by Lawrence Berkeley National Laboratory through the US

591 Department of Energy, Office of Science, under contract number DE-AC02-05CH11231. K. Novick

592 acknowledges support from the NSF Division of Environmental Biology (through grant DEB 1552747).

593 A. Desai acknowledges support from NSF Division of Biological Infrastructure Advances in Biological

594 Informatics (through grant DBI-1457897 and DBI-1062204), and thanks Elisabeth Andrews for editing a

595 previous draft of the manuscript. 


\section{Bibliography}

Alley, W.M., 1984. The Palmer drought severity index: limitations and assumptions. Journal of Climate and Applied Meteorology, 23:1100-1109.

Amiro, B. Barr, A.G., Black, T.A., Iwashita, H., Kljun, N., McCaughey, J.H., Morgenstern, K., Murayama, S., Nesic, Z., Orchansky, A.L., and Saigusa, N., 2006. Carbon, energy and water fluxes at mature and disturbed forest sites, Saskatchewan, Canada. Agricultural and Forest Meteorology, 136: 237-251.

Amiro, B.D., Barr, A.G., Barr, J.G., Black, T.A., Bracho, R., Brown, M., Chen, J., Clark, K.L, Davis, K.J., Desai, A.R., Dore, S., Engel, V., Fuentes, J.D., Goldstein, A.H., Goulden, M.L., Kolb, T.E., Lavigne, M.B., Law, B.E., Margolis, H.A., Martin, T., McCaughey, J.H., Misson, L., MontesHelu, M., Noormets, A., Randerson, J.T., Starr, G., and Xiao, J., 2010. Ecosystem carbon dioxide fluxes after disturbance in forests of North America. Journal of Geophysical ResearchBiogeosciences, 115: G00K02, doi:10.1029/2010JG001390.

Anderegg, W.R., Schwalm, C., Biondi, F., Camarero, J.J., Koch, G., Litvak, M., Ogle, K., Shaw, J.D., Shevliakova, E., Williams, A.P., Wolf, A., Ziaco, E., and Pacala, S., 2015. Pervasive drought legacies in forest ecosystems and their implications for carbon cycle models. Science, 349: 528532.

Anderson-Teixeira, K.J., Delong, J.P., Fox, A.M., Brese, D.A. and Litvak, M.E., 2011. Differential responses of production and respiration to temperature and moisture drive the carbon balance across a climatic gradient in New Mexico. Global Change Biology, 17: 410-424.

Asaf, D., Rotenber, E., Tatarinov, F., Dicken, U., Montzka, S.A., and Yakir, D., 2013. Ecosystem photosynthesis inferred from measurements of carbonyl sulphide flux. Nature Geoscience, 6 : 186-190.

Aubinet, M., Grelle, A., Ibrom, A., Rannik, Ü., Moncrieff, J., Foken, T., Kowalski, A.S., Martin, P.H., Berbigier, P., Bernhofer, C., Clement, R., Elber, J., Granier, A., Grünwald, T., Morgenstern, K., 
Pilegaard, K., Rebmann, C., Snijders, W., Valentini, R., and Vesala, T., 1999. Estimates of the annual net carbon and water exchange of forests: the EUROFLUX methodology. Advances in Ecological Research, 30: 113-175.

Babst, F., Alexander, M.R., Szejner, P., Bouriaud, O., Klesse, S., Roden, J., Ciais, P., Poulter, B., Frank, D., Moore, D.J. and Trouet, V., 2014. A tree-ring perspective on the terrestrial carbon cycle. Oecologia, 176: 307-322.

Baker, J. and Griffis, T., 2005. Examining strategies to improve the carbon balance of corn/soybean agriculture using eddy covariance and mass balance techniques. Agricultural and Forest Meteorology, 128: 163-177.

Baldocchi, D., 2008. Breathing of the terrestrial biosphere: lessons learned from a global network of carbon dioxide flux measurement systems. Australian Journal of Botany, 56: 1-26.

Baldocchi, D., Falge, E., Gu, L., Olson, R., Hollinger, D., Running, S., Anthoni, P., Bernhofer, C., Davis, K., Evans, R. Fuentes, J., Goldstein, A., Katul, G., Law, B.E., Lee, X., Malhi, Y., Meyers, T.P., Munge,r W., Oechel, W., Paw U., K.T., Pilegaard, K., Schmid, H.P., Valentini, R., Verma, S., Vesala, T., Wilson, K., and Wofsy, S., 2001. FLUXNET: A new tool to study the temporal and spatial variability of ecosystem-scale carbon dioxide, water vapor, and energy flux densities. Bulletin of the American Meteorological Society, 82: 2415-2434.

Baldocchi, D. and Ma, S.Y., 2013. How will land use affect air temperature in the surface boundary layer? Lessons learned from a comparative study on the energy balance of an oak savanna and annual grassland in California, USA. Tellus Series B-Chemical and Physical Meteorology, 65: 19994.

Baldocchi, D.D., 2003. Assessing the eddy covariance technique for evaluating carbon dioxide exchange rates of ecosystems: past, present and future. Global Change Biology, 9: 479-492.

Baldocchi, D.D. and Vogel, C.A., 1996. Energy and CO 2 flux densities above and below a temperate broad-leaved forest and a boreal pine forest. Tree Physiology, 16: 5-16. 
652

653

654

655

656

657

658

659

660

661

662

663

664

665

666

667

668

669

670

671

672

673

674

675

676

Barry, R., 1970. A framework for climatological research with particular reference to scale concepts. Transactions of the Institute of British Geographers, 49: 61-70.

Beringer, J., Hutley, L.B., McHugh, I., Arndt, S.K., Campbell, D., Cleugh, H.A., Cleverly, J., Resco de Dios, V., Eamus, D., Evans, B., Ewenz, C., Grace, P., Griebel, A., Haverd, V., Hinko-Najera, N., Huete, A., Isaac, P., Kanniah, K., Leuning, R., Liddell, M.J., Macfarlane, C., Meyer, W., Moore, C., Pendall, E., Phillips, A., Phillips, R.L., Prober, S.M., Restrepo-Coupe, N., Rutledge, S., Schroder, I., Silberstein, R., Southall, R., Yee, M.S., van Gorsel, E., Vote, C., Walker, J., and Wardlaw, T., 2016. An introduction to the Australian and New Zealand flux tower networkOzFlux. Biogeosciences, 13: 5895-5916.

Biederman, J.A., Scott, R.L., Goulden, M.L., Vargas, R., Litvak, M.E., Kolb, T.E., Yepez, E.A., Oechel, W.C., Blanken, P.D., Bell, T.W., Garatuza-Payan, J., Mauerer, G.E., Dore, S., and Burns, S.P., 2016. Terrestrial carbon balance in a drier world: the effects of water availability in southwestern North America. Global Change Biology, 22: 1867-1879.

Billesbach, D.P., Berry, J.A., Seibt, U., Maseyk, K., Torn, M.S., Fischer, M.L., Abu-Naser, M. and Campbell, J.E., 2014. Growing season eddy covariance measurements of carbonyl sulfide and $\mathrm{CO}_{2}$ fluxes: $\mathrm{COS}$ and $\mathrm{CO}_{2}$ relationships in Southern Great Plains winter wheat. Agricultural and Forest Meteorology, 184: 48-55.

Billesbach, D., Fischer, M., Torn, M. and Berry, J., 2004. A portable eddy covariance system for the measurement of ecosystem-atmosphere exchange of $\mathrm{CO} 2$, water vapor, and energy. Journal of Atmospheric and Oceanic Technology, 21: 639-650.

Boden, T.A., Krassovski, M. and Yang, B., 2013. The AmeriFlux data activity and data system: an evolving collection of data management techniques, tools, products and services. Geoscientific Instrumentation, Methods and Data Systems, 2: 165-176.

Bohrer, G., Gu., L., Gurney, K., Law, B., McFadden, J., Noormets, A., Pardyjak, E., Poindexter, C., Stoll, R., and Torn, M.S., 2015. An AmeriFlux network perspective on urban and managed systems, 
AmeriFlux Management Project, U.S. DOE BERAC Workshop on the potential Integrated Field Laboratory (IFL). Available online at: http://ameriflux.lbl.gov/resources/reports/

Booth, B.B., Jones, C.D., Collins, M., Totterdell, I.J., Cox, P.M., Sitch, S., Huntingford, C., Betts, R.A., Harris, G.R. and Lloyd, J., 2012. High sensitivity of future global warming to land carbon cycle processes. Environmental Research Letters., 7: 024002.

Braswell, B. H., Sacks, W. J., Linder, E., and Schimel, D. S., 2005. Estimating diurnal to annual ecosystem parameters by synthesis of a carbon flux model with eddy covariance net ecosystem exchange observations. Global Change Biology, 11: 335-355.

Brown, T.B., Hultine, K.R., Steltzer, H., Denny, E.G., Denslow, M.W., Granados, J., Henderson, S., Moore, D., Nagai, S., SanClements, M. and Sánchez-Azofeifa, A., 2016. Using phenocams to monitor our changing Earth: toward a global phenocam network. Frontiers in Ecology and the Environment, 14: 84-93.

Brzostek, E.R., Dragoni, D., Schmid, H.P., Rahman, A.F., Sims, D., Wayson, C.A., Johnson, D.J. and Phillips, R.P., 2014. Chronic water stress reduces tree growth and the carbon sink of deciduous hardwood forests. Global Change Biology, 20: 2531-2539.

Burba, G.G., McDermitt, D.K., Anderson, D.J., Furtaw, M.D. and Eckles, R.D., 2011. Novel design of an enclosed $\mathrm{CO}(2) / \mathrm{H}(2) \mathrm{O}$ gas analyser for eddy covariance flux measurements. Tellus Series BChemical and Physical Meteorology, 62: 743-748.

Burba, G.G., McDermitt, D.K., Grelle, A., Anderson, D.J. and Xu, L.K., 2008. Addressing the influence of instrument surface heat exchange on the measurements of $\mathrm{CO}(2)$ flux from open-path gas analyzers. Global Change Biology, 14: 1854-1876.

Campbell, J.E., Whelan, M.E., Seibt, U., Smith, S.J., Berry, J.A. and Hilton, T.W., 2015. Atmospheric carbonyl sulfide sources from anthropogenic activity: Implications for carbon cycle constraints. Geophysical Research Letters, 42: 3004-3010. 
Carpenter, S. R., \& Turner, M. G., 2000. Hares and tortoises: interactions of fast and slow variables in ecosystems. Ecosystems, 3: 495-497.

Chen, H., Tian, H., Liu, M. and Melillo, J., 2006. Effect of land-cover change on terrestrial carbon dynamics in the southern United States. Journal of Environmental Quality, 35: 1533-1547.

Chorover, J., Scatena, F.N., White, T., Anderson, S., Aufdenkampe, A.K., Bales, R.C., Brantley, S.L., and Tucker, G., 2012. Common Critical Zone Observatory (CZO) Infrastructure and Measurements. A Guide Prepared by CZO PIs. Avilable online at http://criticalzone.org/christina/publications/report-proposal/.

Chu, H., Baldocchi, D.D., John, R., Wolf, S. and Reichstein, M., 2017. Fluxes all of the time? A primer on the temporal representativeness of FLUXNET. Journal of Geophysical Research: Biogeosciences, 122: 289-307.

Clark, K.L., Gholz, H.L. and Castro, M.S., 2004. Carbon dynamics along a chronosequence of slash pine plantations in north Florida. Ecological Applications, 14: 1154-1171.

Decker, M., Brunke, M.A., Wang, Z., Sakaguchi, K., Zeng, X. and Bosilovich, M.G., 2012. Evaluation of the reanalysis products from GSFC, NCEP, and ECMWF using flux tower observations. Journal of Climate, 25: 1916-1944.

Desai, A.R., 2010. Climatic and phenological controls on coherent regional interannual variability of carbon dioxide flux in a heterogeneous landscape. Journal of Geophysical Research: Biogeosciences, 115: G00J02.

Desai, A.R., Noormets, A.N., Bolstad, P.V., Chen, J., Cook, B.D., Davis, K.J., Euskirchen, E.S., Gough, C.M., Martin, J.G., Ricciuto, D.M., Schmid, H.P., Tang, J.W. and Wang, W., 2008a. Influence of vegetation and seasonal forcing on carbon dioxide fluxes across the Upper Midwest, USA: Implications for regional scaling. Agricultural and Forest Meteorology, 148: 288-308. 
Desai, A.R., Richardson, A.D., Moffat, A.M., Kattge, J., Hollinger, D.Y., Barr, A., Falge, E., Noormets, A., Papale, D., Reichstein, M. and Stauch, V.J., 2008b. Cross-site evaluation of eddy covariance GPP and RE decomposition techniques. Agricultural and Forest Meteorology, 148: 821-838.

Detto, M., Verfaillie, J., Anderson, F., Xu, L. and Baldocchi, D., 2011. Comparing laser-based open-and closed-path gas analyzers to measure methane fluxes using the eddy covariance method. Agricultural and Forest Meteorology, 151: 1312-1324.

Dietze, M., 2017. Ecological Forecasting. Princeton University Press, Princeton, NJ, 288 pp.

Dietze, M.C., Serbin, S.P., Davidson, C., Desai, A.R., Feng, X., Kelly, R., Kooper, R., LeBauer, D., Mantooth, J., McHenry, K. and Wang, D., 2014. A quantitative assessment of a terrestrial biosphere model's data needs across North American biomes. Journal of Geophysical Research: Biogeosciences, 119: 286-300.

Dragoni, D., Schmid, H.P., Wayson, C.A., Potter, H., Grimmond, C.S.B. and Randolph, J.C., 2011. Evidence of increased net ecosystem productivity associated with a longer vegetated season in a deciduous forest in south-central Indiana, USA. Global Change Biology, 17: 886-897.

Dye, A., Barker Plotkin, A., Bishop, D., Pederson, N., Poulter, B. and Hessl, A., 2016. Comparing tree-ring and permanent plot estimates of aboveground net primary production in three eastern US forests. Ecosphere, 7: e01454.

Ellison, D., Morris, C.E., Locatelli, B., Sheil, D., Cohen, J., Murdiyarso, D., Gutierrez, V., Van Noordwijk, M., Creed, I.F., Pokorny, J., Gaveau, D., Spracklen, D.V., Tobella, A.B., Ilstedt, U., Teuling, A.J., Gebrehiwot, S.G., Sands, D.C., Muys, B., Verbist, B., Springgay, E., Sugandi, Y., and Sullivan, C.A., 2017. Trees, forests and water: Cool insights for a hot world. Global Environmental Change, 43: 51-61.

Fisher, J.B., Melton, F., Middleton, E., Hain, C., Anderson, M., Allen, R., McCabe, M.F., Hook, S., Baldocchi, D., Townsend, P.A. Kilic, A., Tu, K., Miralles, D.D., Perret, J., Lagouarde, J.-P., Waliser, D., Purdy, A.J., French, A., Schimel, D., Famigliette, J.S., Stephens, G., and Wood, E.F., 2017. The Future of Evapotranspiration: Global requirements for ecosystem functioning, carbon 
and climate feedbacks, agricultural management, and water resources. Water Resources Research, 53, doi:10.1002/2016WR020175.

Foken, T., 2008. The energy balance closure problem: An overview. Ecological Applications, 18: 13511367.

Frank, J.M., Massman, W.J., Swiatek, E., Zimmerman, H.A. and Ewers, B.E., 2016. All sonic anemometers need to correct for transducer and structural shadowing in their velocity measurements. Journal of Atmospheric and Oceanic Technology, 33: 149-167.

Frankenberg, C., O'Dell, C., Berry, J., Guanter, L., Joiner, J., Köhler, P., Pollock, R. and Taylor, T.E., 2014. Prospects for chlorophyll fluorescence remote sensing from the Orbiting Carbon Observatory-2. Remote Sensing of Environment, 147: 1-12.

Franklin, J.F., Bledsoe, C.S. and Callahan, J.T., 1990. Contributions of the long-term ecological research program. BioScience, 40: 509-523.

Friedlingstein, P., Meinshausen, M., Arora, V.K., Jones, C.D., Anav, A., Liddicoat, S.K. and Knutti, R., 2014. Uncertainties in CMIP5 climate projections due to carbon cycle feedbacks. Journal of Climate, 27: 511-526.

Goring, S.J., Weathers, K.C., Dodds, W.K., Soranno, P.A., Sweet, L.C., Cheruvelil, K.S., Kominoski, J.S., Rüegg, J., Thorn, A.M. and Utz, R.M., 2014. Improving the culture of interdisciplinary collaboration in ecology by expanding measures of success. Frontiers in Ecology and the Environment, 12: 39-47.

Gough, C.M., Hardiman, B.S., Nave, L.E., Bohrer, G., Maurer, K.D., Vogel, C.S., Nadelhoffer, K.J. and Curtis, P.S., 2013. Sustained carbon uptake and storage following moderate disturbance in a Great Lakes forest. Ecological Applications, 23: 1202-1215.

Goulden, M.L., Munger, J.W., Fan, S.M., Daube, B.C. and Wofsy, S.C., 1996. Measurements of carbon sequestration by long-term eddy covariance: Methods and a critical evaluation of accuracy. Global Change Biology, 2: 169-182. 
775

776

777

778

779

780

781

782

783

784

785

786

787

788

789

790

791

792

793

794

795

796

797

798

799

800

Hampton, S.E., Strasser, C.A., Tewksbury, J.J., Gram, W.K., Budden, A.E., Batcheller, A.L., Duke, C.S. and Porter, J.H., 2013. Big data and the future of ecology. Frontiers in Ecology and the Environment, 11: 156-162.

Hara, N., Solomon, P., Kim, S.L. and Sonnenwald, D.H., 2003. An emerging view of scientific collaboration: Scientists' perspectives on collaboration and factors that impact collaboration. Journal of the American Society for Information Science and Technology, 54: 952-965.

Heidorn, P.B., 2008. Shedding light on the dark data in the long tail of science. Library Trends, 57: 280299.

Hill, T., Chocholek, M. and Clement, R., 2017. The case for increasing the statistical power of eddy covariance ecosystem studies: why, where and how? Global Change Biology, 23: 2154-2165.

Hobbie, J.E., Carpenter, S.R., Grimm, N.B., Gosz, J.R. and Seastedt, T.R., 2003. The US long term ecological research program. BioScience, 53: 21-32.

Hollinger, D.Y., Aber, J., Dail, B., Davidson, E.A., Goltz, S.M., Hughes, H., Leclerc, M.Y., Lee, J.T., Richardson, A.D., Rodrigues, C., Scott, N.A., Achuatavarier, D., and Walsh, J., 2004. Spatial and temporal variability in forest-atmosphere CO2 exchange. Global Change Biology, 10: 1689-1706.

Hollinger, D.Y., Goltz, S.M., Davidson, E.A., Lee, J.T., Tu, K. and Valentine, H.T., 1999. Seasonal patterns and environmental control of carbon dioxide and water vapour exchange in an ecotonal boreal forest. Global Change Biology, 5: 891-902.

Hui, D., Luo, Y. and Katul, G., 2003. Partitioning interannual variability in net ecosystem exchange between climatic variability and functional change. Tree physiology, 23: 433-442.

Huntzinger, D.N., Post, W.M., Wei, Y., Michalak, A.M., West, T.O., Jacobson, A.R., Baker, I.T., Chen, J.M., Davis, K.J., Hayes, D.J., Hoffman, F.M., Jain, A.K., Liu, S., McGuire, A.D., Neilson, R.P., Potter, C., Poulter, B., Prince, D., Raczka, B.M., Tian, H.Q., Thornton, P., Tomelleri, E., Viovy, N., Xiao, J., Yuan, W., Zeng, N., Zhao, M., and Cook, R., 2012. North American Carbon Program (NACP) regional interim synthesis: Terrestrial biospheric model intercomparison. Ecological Modelling, 232: 144-157. 
801

Jones, K.B., Bogena, H., Vereecken, H. and Weltzin, J.F., 2010. Design and importance of multi-tiered ecological monitoring networks, Long-Term Ecological Research. Springer, pp. 355-374.

Jones, L., Kimball, J.S., Reichle, R.H., Madani, N., Glassy, J., Ardizzone, J., Colliander, A., Cleverly, J., Desai, A.R., Eamus, D., Euskirchen, E., Hutley, L., MacFarlane , C., and Scott, R., 2017. The SMAP Level 4 Carbon Product for Monitoring Ecosystem Land-Atmosphere CO2 Exchange. IEEE Transactions on Geoscience and Remote Sensing, \#TGRS-2016-01206, in press. DOI: 10.1109/TGRS.2017.2729343.

Juang, J.Y., Katul, G., Siqueira, M., Stoy, P. and Novick, K., 2007. Separating the effects of albedo from eco-physiological changes on surface temperature along a successional chronosequence in the southeastern United States. Geophysical Research Letters, 34: L21408.

Jung, M., Reichstein, M., Ciais, P., Seneviratne, S.I., Sheffield, J., Goulden, M.L., Bonan, G., Cescatti, A., Chen, J., De Jeu, R., Dolman, A.J., Eugster, W., Gerten, D., Gianelle, D., Gobron, N., Heinke, J., Kimball, J., Law, B.E., Montagnani, L., Mu, Q., Mueller, B., Oleson, K., Papale, D., Richardson, A.D., Roupsard, O., Running, S., Tomelleri, E., Viovy, N., Weber, U., Williams, C., Wood, E., Zaehle, S., and Zhang, K., 2010. Recent decline in the global land evapotranspiration trend due to limited moisture supply. Nature, 467: 951-954.

Kalnay, E., 2003. Atmospheric modeling, data assimilation and predictability. Cambridge University Press.

Keenan, T. F., Davidson, E. A., Munger, J. W. and Richardson, A. D., 2013. Rate my data: quantifying the value of ecological data for the development of models of the terrestrial carbon cycle. Ecological Applications, 23: 273-286.

Keller, M., Schimel, D.S., Hargrove, W.W. and Hoffman, F.M., 2008. A continental strategy for the National Ecological Observatory Network. Frontiers in Ecology and the Environment, 6: 282284. 
Knapp, A.K., Smith, M.D., Hobbie, S.E., Collins, S.L., Fahey, T.J., Hansen, G.J., Landis, D.A., La Pierre, K.J., Melillo, J.M., Seastedt, T.R., Shaver, G.R., and Webster, J., 2012. Past, present, and future roles of long-term experiments in the LTER network. BioScience, 62: 377-389.

Lasslop, G., Reichstein, M., Papale, D., Richardson, A.D., Arneth, A., Barr, A., Stoy, P. and Wohlfahrt, G., 2010. Separation of net ecosystem exchange into assimilation and respiration using a light response curve approach: critical issues and global evaluation. Global Change Biology, 16: 187208.

Law, B., 2005. Carbon dynamics in response to climate and disturbance: recent progress from multi-scale measurements and modeling in AmeriFlux, Plant Responses to Air Pollution and Global Change. Springer, pp. 205-213.

Law, B.E., Sun, O., Campbell, J., Van Tuyl, S. and Thornton, P., 2003. Changes in carbon storage and fluxes in a chronosequence of ponderosa pine. Global Change Biology, 9: 510-524.

Law, B.E., Turner, D., Campbell, J., Sun, O.J., Van Tuyl, S., Ritts, W.D. and Cohen, W.B., 2004. Disturbance and climate effects on carbon stocks and fluxes across Western Oregon USA. Global Change Biology, 10(9): 1429-1444.

Lee, X., Finnigan, J. and Paw U, K., 2005. Coordinate systems and flux bias error. Handbook of Micrometeorology 29: 33-66.

Lee, X., Goulden, M.L., Hollinger, D.Y., Barr, A., Black, T.A., Bohrer, G., Bracho, R., Drake, B., Goldstein, A., Gu, L. Katul, G., Kolb, T., Law, B.E., Margolis, H., Meyers, T., Monson, R., Munger, W., Oren, R., Paw U, K.T., Richardson, A., Schimd, H.P., Staebler, R., Wofsy, S., and Zhao, L., 2011. Observed increase in local cooling effect of deforestation at higher latitudes. Nature, 479: 384-387.

Levis, S., Bonan, G.B., Kluzek, E., Thornton, P.E., Jones, A., Sacks, W.J. and Kucharik, C.J., 2012. Interactive crop management in the Community Earth System Model (CESM1): Seasonal influences on land-atmosphere fluxes. Journal of Climate, 25: 4839-4859. 
Lewis, J.M., Ross, S. and Holden, T., 2012. The how and why of academic collaboration: disciplinary differences and policy implications. Higher Education, 64: 693-708.

Luo, Y.Q., Randerson, J.T., Abramowitz, G., Bacour, C., Blyth, E., Carvalhais, N., Ciais, P., Dalmonech, D., Fisher, J.B., Fisher, R., Friedlingstein, P., Hibbard, K., Hoffman, F., Huntzinger, D., Jones, C.D., Koven, C., Lawrence, D., Li, D.J., Mahecha, M., Niu, S.L., Norby, R., Piao, S.L., Qi, X., Peylin, P., Prentice, I.C., Riley, W., Reichstein, M., Schwalm, C., Wang, Y.P., Xia, J.Y., Zaehle, S., and Zhoe, X.H., 2012. A framework for benchmarking land models. Biogeosciences, 9: 38573874.

Mammarella, I., Werle, P., Pihlatie, M., Eugster, W., Haapanala, S., Kiese, R., Markkanen, T., Rannik, U. and Vesala, T., 2010. A case study of eddy covariance flux of $\mathrm{N} 2 \mathrm{O}$ measured within forest ecosystems: quality control and flux error analysis. Biogeosciences, 7: 427-440.

Massman, W.J., 2000. A simple method for estimating frequency response corrections for eddy covariance systems. Agricultural and Forest Meteorology, 104: 185-198.

Massman, W.J., 2001. Reply to comment by Rannik on "A simple method for estimating frequency response corrections for eddy covariance systems". Agricultural and Forest Meteorology, 107: 247-251.

Maurer, G.E., Chan, A.M., Trahan, N.A., Moore, D.J. and Bowling, D.R., 2016. Carbon isotopic composition of forest soil respiration in the decade following bark beetle and stem girdling disturbances in the Rocky Mountains. Plant, Cell \& Environment, 39: 1513-1523.

McDermitt, D., Burba, G., Xu, L., Anderson, T., Komissarov, A., Riensche, B., Schedlbauer, J., Starr, G., Zona, D., Oechel, W., Oberbauer, S., and Hastings, S., 2011. A new low-power, open-path instrument for measuring methane flux by eddy covariance. Applied Physics B: Lasers and Optics, 102: 391-405.

Metzger, S., Durden, D., Sturtevant, C., Luo, H., Pingintha-Durden, N., Sachs, T., Serafimovich, A., Hartmann, J., Li, J., Xu, K., Desai, A.R., 2017. eddy4R: A community-extensible processing, 
analysis and modeling framework for eddy-covariance data based on R, Git, Docker and HDF5. Geoscientific Model Development Discuss., 10, 3189-3206.

Mizoguchi, Y., Miyata, A., Ohtani, Y., Hirata, R. and Yuta, S., 2009. A review of tower flux observation sites in Asia. Journal of Forest Research, 14: 1-9.

Moncrieff, J., Clement, R., Finnigan, J. and Meyers, T., 2005. Averaging, detrending, and filtering of eddy covariance time series. Handbook of Micrometeorology, 29: 297-31.

Montané, F., Fox, A. M., Arellano, A. F., MacBean, N., Alexander, M. R., Dye, A., Bishop, D. A., Trouet, V., Babst, F., Hessl, A. E., Pederson, N., Blanken, P. D., Bohrer, G., Gough, C. M., Litvak, M. E., Novick, K. A., Phillips, R. P., Wood, J. D., and Moore, D. J. P.:,2017. Evaluating the effect of alternative carbon allocation schemes in a land surface model (CLM4.5) on carbon fluxes, pools and turnover in temperate forests, Geosci. Model Dev. Discuss., doi:10.5194/gmd2017-74, in press. DOI: doi:10.5194/gmd-2017-74.

Moorcroft, P.R., 2006. How close are we to a predictive science of the biosphere? Trends in Ecology \& Evolution, 21: 400-407.

Moore, D.J., Hu, J., Sacks, W.J., Schimel, D.S. and Monson, R.K., 2008. Estimating transpiration and the sensitivity of carbon uptake to water availability in a subalpine forest using a simple ecosystem process model informed by measured net $\mathrm{CO}_{2}$ and $\mathrm{H}_{2} \mathrm{O}$ fluxes. Agricultural and Forest Meteorology, 148: 1467-1477.

Moore, D.J., Trahan, N.A., Wilkes, P., Quaife, T., Stephens, B.B., Elder, K., Desai, A.R., Negron, J. and Monson, R.K., 2013. Persistent reduced ecosystem respiration after insect disturbance in high elevation forests. Ecology Letters 16: 731-737.

Nippert, J.B., Ocheltree, T.W., Skibbe, A.M., Kangas, L.C., Ham, J.M., Arnold, K.B.S. and Brunsell, N.A., 2011. Linking plant growth responses across topographic gradients in tallgrass prairie. Oecologia, 166: 1131-1142. 
Nishida, K., Nemani, R.R., Running, S.W. and Glassy, J.M., 2003. An operational remote sensing algorithm of land surface evaporation. Journal of Geophysical Research: Atmospheres, 108: 4270.

Novick, K.A., Ficklin, D.L., Stoy, P.C., Williams, C.A., Bohrer, G., Oishi, A.C., Papuga, S.A., Blanken, P.D., Noormets, A., Sulman, B.N., Scott, R.L., Wang, L, and Phillips, R.P., 2016a. The increasing importance of atmospheric demand for ecosystem water and carbon fluxes. Nature Climate Change, 6: 1023-1027.

Novick, K.A., Oishi, A.C., and Miniat, C.F., 2016b. Cold air drainage flows subsidize montane valley ecosystem productivity. Global Change Biology, 22: 4014-4027.

Novick, K.A., Oishi, A.C., Ward, E.J., Siqueira, M., Juang, J.Y. and Stoy, P.C., 2015. On the difference in the net ecosystem exchange of $\mathrm{CO} 2$ between deciduous and evergreen forests in the southeastern U.S. Global Change Biology, 21: 827-842. .

Novick, K.A., Walker, J.T., Chan, W.S., Sobek, C.M. and Vose, J.M., 2013. Eddy covariance measurements with a new fast-response, closed-path analyzer: spectral characteristics and crosssystem comparisions. Agricultural and Forest Meteorology, 181: 17-32.

Pastorello, G., Papale, D., Chu, H., Trotta, C., Agarwal, D., Canfora, E., Baldocchi, D. and Torn, M., 2017. A New Data Set to Keep a Sharper Eye on Land-Air Exchanges. EOS 98, https://doi.org/10.1029/2017E0071597. Published on 17 April 2017.

Peters, D.P., Groffman, P.M., Nadelhoffer, K.J., Grimm, N.B., Collins, S.L., Michener, W.K. and Huston, M.A., 2008. Living in an increasingly connected world: a framework for continental-scale environmental science. Frontiers in Ecology and the Environment, 6: 229-237.

Peters, D.P., Havstad, K.M., Cushing, J., Tweedie, C., Fuentes, O. and Villanueva-Rosales, N., 2014. Harnessing the power of big data: infusing the scientific method with machine learning to transform ecology. Ecosphere, 5: 1-15. 
Phillips, C.L., Bond-Lamberty, B., Desai, A.R., Lavoie, M., Risk, D., Tang, J., Todd-Brown, K. and Vargas, R., 2017. The value of soil respiration measurements for interpreting and modeling terrestrial carbon cycling. Plant and Soil, 413: 1-25.

Reichman, O.J., Jones, M.B. and Schildhauer, M.P., 2011. Challenges and opportunities of open data in Ecology. Science, 331: 703-705.

Reichstein, M., Falge, E., Baldocchi, D., Papale, D., Aubinet, M., Berbigier, P., Bernhofer, C., Buchmann, N., Gilmanov, T., Granier, A. and Grünwald, T., Havránková, K., Ilvesniemi, H., Janous, D., Knohl, A., Laurila, T., Lohila, A., Loustau, D., Matteucci, G., Meyers, T., Miglietta, F., Ourcival, J.-M., Pumpanen, J., Rambal, S., Rotenberg, E., Sanz, M., Tenhunen, J., Seufert, G., Vaccari, F., Vesala, T., Yakir, D., Valentinie, R., 2005. On the separation of net ecosystem exchange into assimilation and ecosystem respiration: review and improved algorithm. Global Change Biology, 11: 1424-1439.

Reichstein, M. and Moffat, A., 2014. REddyProc: Data processing and plotting utilities of (half-) hourly eddy-covariance measurements. R package version 0.6-0/r9. https://rdrr.io/rforge/REddyProc/

Richardson, A.D., Anderson, R.S., Arain, M.A., Barr, A.G., Bohrer, G., Chen, G., Chen, J.M., Ciais, P., Davis, K.J., Desai, A.R., Dietze, M.C., Dragoni, D., Garrity, S.R., Gough, C.M., Grant, R., Hollinger, D.Y., Margolis, H.A., McCaughey, H., Migliavacca, M., Monson, R.K., Munger, J.W., Poulter, B., Raczka, B.M., Ricciuto, D.M., Sahoo, A.K., Schaefer, K., Tian, H., Vargas, R., Verbeeck, H., Xiao, J., and Xue, Y., 2012. Terrestrial biosphere models need better representation of vegetation phenology: results from the North American Carbon Program Site Synthesis. Global Change Biology, 18: 566-584.

Richardson, A.D., Williams, M., Hollinger, D.Y., Moore, D.J., Dail, D.B., Davidson, E.A., Scott, N.A., Evans, R.S., Hughes, H., Lee, J.T., Rodrigues, C., and Savage, K., 2010. Estimating parameters of a forest ecosystem $\mathrm{C}$ model with measurements of stocks and fluxes as joint constraints. Oecologia, 164: 25-40. 
Richardson, A.D., Hollinger, D.Y., Aber, J.D., Ollinger, S.V. and Braswell, B.H., 2007. Environmental variation is directly responsible for short- but not long-term variation in forest-atmosphere carbon exchange. Global Change Biology, 13: 788-803.

Richardson, A.D., Hollinger, D.Y., Burba, G.G., Davis, K.J., Flanagan, L.B., Katul, G.G., Munger, J.W., Ricciuto, D.M., Stoy, P.C., Suyker, A.E., Verma, S.B., and Wofsy, S.C., 2006. A multi-site analysis of random error in tower-based measurements of carbon and energy fluxes. Clo, 136: 118.

Richter, D. and Billings, S.A., 2015. 'One physical system': Tansley's ecosystem as Earth's critical zone. New Phytologist, 206(3): 900-912.

Rigden, A.J. and Salvucci, G.D., 2017. Stomatal response to humidity and CO2 implicated in recent decline in US evaporation. Global Change Biology, 23: 1140-1151.

Roman, D.T., Novick, K.A., Brzostek, E.R., Dragoni, D., Rahman, F. and Phillips, R.P., 2015. The role of isohydric and anisohydric species in determining ecosystem-scale response to severe drought. Oecologia, 179: 641-654.

Rundel, P.W., Graham, E.A., Allen, M.F., Fisher, J.C. and Harmon, T.C., 2009. Environmental sensor networks in ecological research. New Phytologist, 182: 589-607.

Runkle, B.R., Rigby, J.R., Reba, M.L., Anapalli, S.S., Bhattacharjee, J., Krauss, K.W., Liang, L., Locke, M.A., Novick, K.A., Sui, R. Suvočarev, K., and White, P.M., 2017. Delta-Flux: An Eddy Covariance Network for a Climate-Smart Lower Mississippi Basin. Agricultural \& Environmental Letters, 2: 170003.

Running, S.W., Nemani, R.R., Heinsch, F.A., Zhao, M., Reeves, M. and Hashimoto, H., 2004. A continuous satellite-derived measure of global terrestrial primary production. Bioscience, 54: $547-560$.

Ryan, M.G., Lavigne, M.B. and Gower, S.T., 1997. Annual carbon cost of autotrophic respiration in boreal forest ecosystems in relation to species and climate. Journal of Geophysical Research, 103: 28871-28883. 
Sacks, W.J., Schimel, D.S., Monson, R.K. and Braswell, B.H., 2006. Model-data synthesis of diurnal and seasonal CO2 fluxes at Niwot Ridge, Colorado. Global Change Biology, 12: 240-259.

Schimel, D., 2011. The era of continental-scale ecology. Frontiers in Ecology and the Environment, 9(6): 311-311.

Schimel, D., Hargrove, W., Hoffman, F. and MacMahon, J., 2007. NEON: A hierarchically designed national ecological network. Frontiers in Ecology and the Environment, 5: 59-59.

Schmidt, A., Hanson, C., Chan, W.S. and Law, B.E., 2012. Empirical assessment of uncertainties of meteorological parameters and turbulent fluxes in the AmeriFlux network. Journal of Geophysical Research: Biogeosciences, 117: G04014.

Schwalm, C.R., Williams, C.A., Schaefer, K., Arneth, A., Bonal, D., Buchmann, N., Chen, J., Law, B.E., Lindroth, A., Luyssaert, S., Reichstein, M., and Richardson, A.D., 2010. Assimilation exceeds respiration sensitivity to drought: A FLUXNET synthesis. Global Change Biology, 16: 657-670.

Schwalm, C.R., Williams, C.A., Schaefer, K., Baldocchi, D., Black, T.A., Goldstein, A.H., Law, B.E., Oechel, W.C., Paw U., K.T., and Scott, R.L., 2012. Reduction in carbon uptake during turn of the century drought in western North America. Nature Geoscience, 5: 551-556.

Scott, R.L., Biederman, J.A., Hamerlynck, E.P. and Barron-Gafford, G.A., 2015. The carbon balance pivot point of southwestern US semiarid ecosystems: Insights from the 21st century drought. Journal of Geophysical Research: Biogeosciences, 120: 2612-2624.

Scott, R.L., Hamerlynck, E.P., Jenerette, G.D., Moran, M.S. and Barron-Gafford, G.A., 2010. Carbon dioxide exchange in a semidesert grassland through drought-induced vegetation change. Journal of Geophysical Research-Biogeosciences, 115: G03026.

Seibt, U., Kesselmeier, J., Sandoval-Soto, L., Kuhn, U. and Berry, J., 2010. A kinetic analysis of leaf uptake of COS and its relation to transpiration, photosynthesis and carbon isotope fractionation. Biogeosciences, 7: 333-341.

Serbin, S.P., Singh, A., Desai, A.R., Dubois, S.G., Jablonski, A.D., Kingdon, C.C., Kruger, E.L. and Townsend, P.A., 2015. Remotely estimating photosynthetic capacity, and its response to 
temperature, in vegetation canopies using imaging spectroscopy. Remote Sensing of Environment, 167: 78-87.

Shen, W., Jenerette, G., Hui, D. and Scott, R., 2016. Precipitation legacy effects on dryland ecosystem carbon fluxes: direction, magnitude and biogeochemical carryovers. Biogeosciences, 13: 425-

Stöckli, R., Lawrence, D.M., Niu, G.Y., Oleson, K.W., Thornton, P.E., Yang, Z.L., Bonan, G.B.,

Stoy, P.C., Katul, G., Siqueira, M., Juang, J.-Y., Novick, K.A., McCarthy, H.R., Oishi, A.C., Oren, R., Denning, A.S. and Running, S.W., 2008. Use of FLUXNET in the Community Land Model development. Journal of Geophysical Research: Biogeosciences, 113: G01025. 2008. Role of vegetation in determining carbon sequestration along ecological succession in the southeastern United States. Global Change Biology, 14: 1409-1427.

Stoy, P.C., Mauder, M., Foken, T., Marcolla, B., Boegh, E., Ibrom, A., Arain, M.A., Arneth, A., Aurela, M., Bernhofer, C. and Cescatti, A., 2013. A data-driven analysis of energy balance closure across FLUXNET research sites: The role of landscape scale heterogeneity. Agricultural and Forest Meteorology, 171: 137-152.

Su, H.B., Schmid, H.P., Grimmond, C.S.B., Vogel, C.S. and Oliphant, A.J., 2004. Spectral characteristics and correction of long-term eddy-covariance measurements over two mixed hardwood forests in non-flat terrain. Boundary-Layer Meteorology, 110: 213-253.

van der Tol, C., Berry, J., Campbell, P. and Rascher, U., 2014. Models of fluorescence and photosynthesis for interpreting measurements of solar-induced chlorophyll fluorescence. Journal of Geophysical Research: Biogeosciences, 119: 2312-2327.

Turnipseed, A.A., Blanken, P.D., Anderson, D.E. and Monson, R.K., 2002. Energy budget above a highelevation subalpine forest in complex topography. Agricultural and Forest Meteorology, 110: 177-201. 
1024

1025

1026

1027

1028

1029

1030

1031

1032

1033

1034

1035

1036

1037

1038

1039

1040

1041

1042

1043

1044

1045

1046

1047

Van der Molen, M., Gash, J. and Elbers, J., 2004. Sonic anemometer (co) sine response and flux measurement: II. The effect of introducing an angle of attack dependent calibration. Agricultural and Forest Meteorology, 122: 95-109.

Van Gorsel, E., Delpierre, N., Leuning, R., Black, A., Munger, J.W., Wofsy, S., Aubinet, M., Feigenwinter, C., Beringer, J., Bonal, D. and Chen, B., Chen, J., Clement, R., Davis, K.J., Desai, A.R., Dragoni, D., Etzold, S., Grünwald, T., Gu, L., Heinesch, B., Hutyar, L.R., Jans, W.W.P., Werner, K., Law, B.E., Leclerc, M.Y., Mammarella, I., Montagnani, L., Noormets, A., Rebmann, C., Wharton, S., 2009. Estimating nocturnal ecosystem respiration from the vertical turbulent flux and change in storage of CO2. Agricultural and Forest Meteorology, 149: 1919-1930.

Verma, M., Schimel, D., Evans, B., Frankenberg, C., Beringer, J., Drewry, D.T., Magney, T., Marang, I., Hutley, L., Moore, C., Eldering, A., 2017. Effect of environmental conditions on the relationship between solar induced fluorescence and gross primary productivity at an OzFlux grassland site. Journal of Geophysical Research: Biogeosciences 122: 716-733.

Verma, S.B., Dobermann, A., Cassman, K.G., Walters, D.T., Knops, J.M., Arkebauer, T.J., Suyker, A.E., Burba, G.G., Amos, B., Yang, H., Ginting, D., Hubbard, K.G., Gitelson, A.A., Walter-Shea, E.A., 2005. Annual carbon dioxide exchange in irrigated and rainfed maize-based agroecosystems. Agricultural and Forest Meteorology, 131: 77-96.

Vuichard, N. and Papale, D., 2015. Filling the gaps in meteorological continuous data measured at FLUXNET sites with ERA-Interim reanalysis. Earth System Science Data, 7(2): 157.

Walbridge, M.R. and Shafer, S.R., 2011. A long-term agro-ecosystem research (LTAR) network for agriculture, Proceedings of the Fourth Interagency Conference in the Watersheds: Observing, Studying, and Managing Change, pp. 26-30.

Wang, H., Prentice, I.C., Keenan, T.F., Davis, T.W., Wright, I.J., Cornwell, W.K., Evans, B.J., and Peng, C. Towards a universal model for carbon dioxide uptake by plants. Nature Plants, 3: 734-741. 
Wehr, R., Commane, R., Munger, J.W., McManus, J.B., Nelson, D.D., Zahniser, M.S., Saleska, S.R. and Wofsy, S.C., 2017. Dynamics of canopy stomatal conductance, transpiration, and evaporation in a temperate deciduous forest, validated by carbonyl sulfide uptake. Biogeosciences, 14: 389.

White, T., Brantley, S., Banwart, S., Chorover, J., Dietrich, W., Derry, L., Lohse, K., Anderson, S., Aufdendkampe, A., Bales, R. and Kumar, P., Richter, D., McDowell, B., 2015. The role of critical zone observatories in critical zone science. Developments in Earth Surface Processes, 19: $15-78$.

Wilczak, J.M., Oncley, S.P. and Stage, S.A., 2001. Sonic anemometer tilt correction algorithms. Boundary-Layer Meteorology, 99: 127-150.

Wilson, K., Goldstein, A., Falge, E., Aubinet, M., Baldocchi, D., Berbigier, P., Bernhofer, C., Ceulemans, R., Dolman, H., Field, C. and Grelle, A., Ibrom, A., Law, B.E., Kowalski, A., Meyers, T., Moncrieff, J., Monson, R., Oechel, W., Tenhunen, J., Valentini, R., Verma, S., 2002. Energy balance closure at FLUXNET sites. Agricultural and Forest Meteorology, 113: 223-243.

Wolf, S., Keenan, T.F., Fisher, J.B., Baldocchi, D.D., Desai, A.R., Richardson, A.D., Scott, R.L., Law, B.E., Litvak, M.E., Brunsell, N.A. and Peters, W., van der Laan-Luijkx, I.T., 2016. Warm spring reduced carbon cycle impact of the 2012 US summer drought. Proceedings of the National Academy of Sciences: 201519620.

Xiao, J., Zhuang, Q., Baldocchi, D., Law, B.E., Richardson, A.D., Chen, J., Oren, R., Starr, G., Noormets, A., Ma, S., Verma, S.B., Wharton, S., Wofsy, S.C., Bolstad, P.V., Burns, S.P., Cook, D.R., Curtis, P.S., Drake, B.G., Falk, M., Fischer, M.L, Foster, D.R., Gu, L, Hadley, J.L., Hollinger, D.Y., Katul, G.G., Litvak, M., Martin, T.A., Matamala, R., McNulty, S., Meyers, T.P., Monson, R.K., Munger, J.W., Oechel, W.C., Paw U, K.T., Schmid, H.P., Scott, R.L., Sun, G., Suyker, A.E., Torn, M.S., 2008. Estimation of net ecosystem carbon exchange for the conterminous United States by combining MODIS and AmeriFlux data. Agricultural and Forest Meteorology, 148: $1827-1847$. 
1073

1074

1075

1076

1077

1078

1079

1080

1081

1082

1083

1084

1085

1086

1087

1088

1089

1090

1091

1092

1093

1094

1095

1096

1097

Xiao, J.F., Zhuang, Q., Law, B.E., Baldocchi, D.D., Chen, J., Richardson, A.D., Melillo, J.M., Davis, K.J., Hollinger, D.Y., Wharton, S., Oren, R., Noormets, A., Fischer, M.L., Verma, S.B., Cook, D.R., Sun, G., McNulty, S., Wofsy, S.C., Bolstad, P.V., Burns, S.P., Curtis, P.S., Drake, B.G., Falk, M., Foster, D.R., Gu, L., Hadley, J.L., Katul, G.G., Litvak, M., Ma, S., Martin, T.A., Matamala, R., Meyers, T.P., Monson, R.K., Munger, J.W., Oechel, W.C., Paw U., K.T., Schimd, H.P., Scott, R.L., Starr, G., Suyker, A.E., Torn, M.S., 2011. Assessing net ecosystem carbon exchange of U.S. terrestrial ecosystems by integrating eddy covariance flux measurements and satellite observations. Agricultural and Forest Meteorology, 151: 60-69.

Xu, K., Metzger, S. and Desai, A.R., 2017. Upscaling tower-observed turbulent exchange at fine spatiotemporal resolution using environmental response functions. Agricultural and Forest Meteorology, 232: 10-22.

Yang, X., Tang, J., Mustard, J.F., Lee, J.E., Rossini, M., Joiner, J., Munger, J.W., Kornfeld, A. and Richardson, A.D. 2015. Solar-induced chlorophyll fluorescence that correlates with canopy photosynthesis on diurnal and seasonal scales in a temperate deciduous forest. Geophysical Research Letters, 42: 2977-2987.

Yuan, W., Luo, Y., Richardson, A.D., Oren, R.A.M., Luyssaert, S., Janssens, I.A., Ceulemans, R., Zhou, X., Grünwald, T., Aubinet, M. and Berhofer, C., Baldocchi, D.D., Grünwald, T., Aubinet, M., Berhofer, C., Baldocchi, D.D., Chen, J., Dunn, A., Deforest, J.L., Dragoni, D., Goldstein, A.H., Moors, E., Munger, J.W., Monson, R.K., Suyker, A.E., Starr, G., Scott, R.L., Tenhunen, J., Verma, S.B., Vesala, T., Wofsy, S.C., 2009. Latitudinal patterns of magnitude and interannual variability in net ecosystem exchange regulated by biological and environmental variables. Global Change Biology, 15: 2905-2920.

Zha, T., Xing, Z., Wang, K.-Y., Kellomäki, S. and Barr, A.G., 2007. Total and component carbon fluxes of a Scots pine ecosystem from chamber measurements and eddy covariance. Annals of Botany, 99: 345-353. 
1098

1099

1100

1101

1102

1103

1104

1105

1106

1107

1108

1109

1110

1111

1112

Zobitz, J., Desai, A., Moore, D. and Chadwick, M., 2011. A primer for data assimilation with ecological models using Markov Chain Monte Carlo (MCMC). Oecologia, 167: 599.

Zobitz, J.M., Moore, D.J.P., Sacks, W.J., Monson, R.K., Bowling, D.R. and Schimel, D.S., 2008. Integration of process-based soil respiration models with whole-ecosystem $\mathrm{CO} 2$ measurements. Ecosystems, 11: 250-269.

Zreda, M., Shuttleworth, W.J., Zeng, X., Zweck, C., Desilets, D., Franz, T. and Rosolem, R., 2012. COSMOS: the cosmic-ray soil moisture observing system. Hydrology and Earth System Sciences, 16: 4079-4099.

Zscheischler, J., Fatichi, S., Wolf, S., Blanken, P.D., Bohrer, G., Clark, K., Desai, A.R., Hollinger, D., Keenan, T., Novick, K.A. and Seneviratne, S.I., 2016. Short-term favorable weather conditions are an important control of interannual variability in carbon and water fluxes. Journal of Geophysical Research: Biogeosciences, 121: 2186-2198. 